\title{
Income and energy use in Bangladesh: A household level analysis
}

\section{Crawford School Working Paper 1701 January 2017}

\section{Syed Abul Hasan}

Crawford School of Public Policy, The Australian National University

\section{Pallab Mozumder}

Dept. of Earth and Env. and Dept. of Economics, Florida International University, FL, USA

\section{Abstract}

We examine how energy use at the household level moves with income growth in Bangladesh. Using the 2010 wave of Bangladesh Household Income and Expenditure Survey data, our analyses indicate a U-shaped relationship of both electricity use and other types of energy use (combined) with household consumption. The findings imply that as income grows, households increase their energy use less than proportionally up to a threshold. Energy use beyond the threshold increases at a higher rate than total consumption, particularly for electricity use. We identify the threshold (turning point) for both electricity and other types of energy use. Based on the current level of consumption and its growth, reaching at the turning point would require 17 years for the former category but only 7 years for the latter group. 


\section{Suggested Citation:}

Hasan, S., and Mozumder, P. (2017) Income and energy use in Bangladesh: A household level analysis, Crawford School working paper 1701, January 2017. Crawford School of Public Policy, The Australian National University.

\section{Address for Correspondence:}

Name: Dr. Syed Abul Hasan

Position: Research Officer

Address Crawford School of Public Policy, Australian National University

Tel: +61 261258282

Email: syed.hasan@anu.edu.au

Crawford School of Public Policy

College of Asia and the Pacific

The Australian National University

Canberra ACT 0200 Australia

www.anu.edu.au

The Crawford School of Public Policy is the Australian National University's public policy school, serving and influencing Australia, Asia and the Pacific through advanced policy research, graduate and executive education, and policy impact. 


\title{
Income and energy use in Bangladesh: A household level analysis
}

\author{
Syed Abul Hasan ${ }^{\mathrm{a}, *}$, Pallab Mozumder ${ }^{\mathrm{b}}$ \\ ${ }^{a}$ Crawford School of Public Policy, Australian National University, Canberra, Australia \\ ${ }^{b}$ Dept. of Earth and Env. and Dept. of Economics, Florida International University, FL, USA
}

\begin{abstract}
We examine how energy use at the household level moves with income growth in Bangladesh. Using the 2010 wave of Bangladesh Household Income and Expenditure Survey data, our analyses indicate a U-shaped relationship of both electricity use and other types of energy use (combined) with household consumption. The findings imply that as income grows, households increase their energy use less than proportionally up to a threshold. Energy use beyond the threshold increases at a higher rate than total consumption, particularly for electricity use. We identify the threshold (turning point) for both electricity and other types of energy use. Based on the current level of consumption and its growth, reaching at the turning point would require 17 years for the former category but only 7 years for the latter group.
\end{abstract}

Keywords: Household energy consumption, Energy Engel curve, Turning point JEL-Classification: O13, D12, Q40, Q56

${ }^{*}$ Corresponding author; 3.27 JG Crawford Building, Crawford School of Public Policy, Australian National University, Canberra, Australia, email - syed.hasan@anu.edu.au.

Preprint submitted to Elsevier 


\section{Introduction}

Bangladesh is making steady economic progress in the midst of acute shortage of energy. Per capita annual energy consumption in the country is $371 \mathrm{kWH}$ which is one of the lowest in the world (World Bank, 2016). Electricity is the major source of energy use for most economic activities in Bangladesh. While around $78 \%$ of the population now has access to electricity, highly intermittent power supply makes their life quite miserable (Mujeri et al., 2014). A large portion of households, on the other hand, do not have access to electricity; other sources of energy are also not adequate to meet the rising demand, resulting in a high rate of energy poverty in the country. A recent study finds that 58 percent of rural households in Bangladesh are energy poor compared to the income poverty of 45 percent (Barnes et al., 2011).

The energy resources and infrastructures in Bangladesh are not only inadequate but also poorly managed. In particular, the electricity generation plants have been unable to meet the demand over the past decade. Corruption, high system losses, low plant efficiencies, erratic power supply, electricity theft, blackouts, and poor maintenance are major issues in the power sector in Bangladesh (World Bank, 2017). Unavailability of modern energy leads to a high share (50\%) of energy consumption from traditional sources (such as fuel wood, animal waste and crop residues). Fortunately, the country has small reserves of oil and coal and relatively large reserves of natural gas, to enhance the energy security of the country.

Bangladesh has joined in the group of lower-middle income countries in 2015 and currently has a per captia GDP of US\$1,384 (Finance Division, 2016). Energy consumption rises sharply between per capita income US\$1,000 and US\$10,000, the range in which Bangladesh would belong at least for a decade with the current growth scenario (Mujeri et al., 2014). The country has also set up the agenda to promote itself to a middle-income economy by 2021 that would require an annual GDP growth rate of $7.5-8.0$ percent for the remaining period. Such growths are beyond the historical rates (around 6.3 percent since 2010) and will need substantial improvement in the energy sector as well as the infrastructure of the country (World Bank, 2016). High economic growth is expected to substantially increase the residential use of energy (Burke and Csereklyei, 2016). At the same time, Bangladesh is aiming to ensure access to electricity for $96 \%$ of its citizens 
together with an uninterrupted power supply to the industries (Planning Commission, 2015).

Anticipating rapid increase in the future energy demand, the Government has planned to increase its electricity generation capacity from 14,000 MW in 2015 to 23,000 MW by 2020 . With this goal, the current energy policy of the country largely focuses on expanding energy generation capacity from new sources which combines both large projects based on traditional sources (fossil fuel, hydro and nuclear energy) as well as expanding off grid small projects based on renewable sources (wind, solar and biogas) (Planning Commission, 2015).

While focusing on the energy supply is essential, understanding the demand for energy can provide critical insights for forecasting future consumption. In particular, an effective knowledge of the changes in energy demand with respect to income, illustrated by the Energy Engel Curve (EEC), may provide useful insights into many aspects of consumer behaviour. For example, the EEC may provide important policy implications which can be useful for a country to develop an effective power management strategy. Most importantly, EECs may provide forecasts of future energy demand as a result of changing demographic scenario in an economy. Such forecasts can be useful in predicting changes in demand to match with the energy generation pattern. EECs are also useful to indicate the share of burden borne by the low-income people resulting from a tax imposed on energy (Deaton and Muellbauer, 1980; Banks et al., 1997; Blundell et al., 1998; Almås, 2012; Hasan, 2016).

Most of the studies on Bangladesh that model the relationship between energy consumption and income are based on aggregate data and do not cover the behavioural dynamics at the household level. For instance, Mozumder and Marathe (2007) examine the causal relationship between per capita electricity consumption and per capita GDP in Bangladesh over time. They find a unidirectional causality from per capita GDP to per capita electricity consumption. Interestingly, studies find a similar unidirectional causality for the consumption of natural gas and for the aggregate energy use in the country (e.g., Das et al., 2013; Paul and Uddin, 2011). In contrast, Ruhul et al. (2008) find no causal relation between GDP and energy use for Bangladesh. Among the few studies that rely on household survey data to investigate the dynamics of energy use 
with income, Barnes et al. (2011) estimate an energy poverty line (the critical minimum amount of energy needed to sustain life) for rural Bangladesh.

Amongst studies estimating the EEC (or some variants of it) for other developing countries and for different types of energy, Navajas (2009) explores the contribution of income and other household characteristics to explain household consumption of natural gas and liquefied petroleum (but not electricity) in Argentina. The study estimates the Engel curve for these two types of energy use and explores welfare implications of tariff reforms in natural gas. Somewhat related to this strand of literature, a number of studies investigate the price and income elasticities of electricity consumption. For instance, using cross-sectional survey data, Gundimeda and Köhlin (2008) estimate the price and income elasticities for different types of fuel demand (electricity, kerosene, liquefied petroleum gas and fuelwood) in both urban and rural areas of India for different income groups. In a recent paper, Youn and Jin (2016) study the sensitivity of price increases on household electricity use in Seoul, Korea and find that progressive pricing has substantial curbing effects on household electricity use.

In developed country perspectives, Ironmonger et al. (1984) have estimated the Engel curve for disaggregated energy use for different household groups in Australia. Using longitudinal household expenditure survey data, they estimate the Engel curves for electricity, natural gas, gasoline and other fuels for different demographic groups. They find that while aggregate energy is a necessity, gasoline is a luxury good in Australia. More recently, Meier et al. (2013) estimate the Engel curve for electricity and gas expenditures using British household panel survey data and find that income elasticities for energy spending are U-shaped. They show that income elasticities for both gas and electricity expenses are less than one (implying energy services are a necessity) although they rise in the long-run.

Against this background, we make an attempt to analyse the pattern of energy use at the household level as their income/consumption rise. For our analysis we disaggregate energy use into two major categories, electricity use and all other energy use combined except electricity (other energy hereafter). Using the 2010 round of Bangladesh Household Income and Expenditure Survey (HIES) data, we have estimated EEC for both categories. We employ a wide range of empirical techniques in estimating the Engel 
curve including quantile, nonparametric and semiparamteric regression methods. We find that, up to a certain threshold, the share of both types of energy use go down with rising household consumption. The pattern is opposite after crossing the threshold, which however, varies between the two types of energy use we examined. Our findings imply that as consumption/income grows, households increase their energy use less than proportionally up to a threshold, beyond which they increase it more than proportionally. We identify the threshold level (turning point) for both categories and, relying on the current consumption and its growth, the number of years required to reach at the turning point. Our study contributes to the literature on energy demand by estimating the disaggregated energy Engel curves for Bangladesh and discussing its policy implications for future energy demand in similar countries.

We organise the rest of the article as follows. In Section 2 we discuss the empirical strategy and identification issues. A brief discussion on the data is presented in Section 3. Estimation results are presented and discussed in Section 4. Section 5 concludes.

\section{Empirical strategy and identification}

We use household survey data to estimate the Engel curves for electricity and other energy use. An important consideration in using household surveys is that the expenditure data are more reliable than income, which is particularly true for low-income and agricultural economies (Engel and Kneip, 1996; Deaton, 1997). Thus studies commonly use expenditure instead of income in modeling Engel curves. Furthermore, to capture a range of functional forms, the dependent variables in such models are usually defined as the share of a good in total expenditure (budget share Engel curves) (Lewbel, 2008). Since Bangladesh is a low-income country that relies highly on agriculture, we estimate the budget share Engel curves in our analysis. However, some lumpy non-consumption expenditures are dropped from our sample and thus a primary dependent variable in our analysis is the money spent on electricity use as a share of total consumption. We employ a similar approach for other energy. Following the convention, we model energy share on the logarithm of total consumption.

Engel curve depends on a number of economic and non-economic factors (Assimakopoulos and Domenikos, 1991). Demographic characteristics particularly play an 
important role in modelling the Engel curves. The primary reason is that consumption can be subject to an economy of scale in household size and the proportion of children. However, when demographic characteristics enter linearly in an expenditure share Engel curve, they impose strong restrictions - if one good assumes linearity in (log of) expenditure, all goods need to be the same (Blundell et al., 1998). To ensure the functional flexibility over consumption categories, we employ the log of equivalised consumption. ${ }^{1}$

The functional form of consumption in the models of Engel curve is an empirical issue. Semiparametric (SP) models impose no restrictions on the functional form of the variables which enter nonparamatrically into such specifications. Thus we employ the following SP specification to examine the functional form of consumption in our models

$$
w_{i h}=F\left(\log \overline{y_{h}}\right)+V_{h} \lambda+v_{i h},
$$

where for each energy type $i$ and household $h, w$ is the energy share (with separate models for the use of electricity and other energy), $F$ is an unknown function, $\bar{y}$ is the equivalised consumption, $V$ is a vector of demographic and other relevant control variables that enter into the model linearly and $v$ is the error term $\left[v \sim N I D\left(0, \sigma^{2}\right)\right]$. The vector $V$ in our model includes variables like household size, number of adults, age of household head and its' square and education of household head and spouse. Our models additionally include indicators for urbanisation and district fixed effects (sixty four) to capture the regional heterogeneity. SP estimates from model (1) can be used to partial out the effect of the variables entering linearly into the model, allowing to infer the effect of consumption on energy shares.

Unfortunately, Engel curve models may suffer from endogeneity when energy shares are regressed on total consumption (Summers, 1957). Specifically, a simultaneous decision about consumption together with allocation on each category can make the former endogenous in the models of Engel curve. The usual solution is to employ an Instrumental Variable (IV) technique. We employ the Control Function (CF) approach which run regressions of the endogenous variables on a set of instruments and add the residuals as

\footnotetext{
${ }^{1}$ The equivalised consumption is generated by dividing household consumption with an equivalence scale (ES) for Bangladesh and then taking the logarithm of the resulting number. We specifically use the ES identified in Hasan (2016), which rely on the same data and follows a semiparametric technique to identify the scale. The employed functional form in the ES allows for a monotonically increasing economy of scale in household size and proportion of children. See Hasan (2016), for details.
} 
additional covariates in the original model. Running nonparametric regressions of the endogenous variable(s) on the instrument(s), saving residuals and including it in the SP models can also control for endogeneity in such models (Newey et al., 1999). While the $\mathrm{CF}$ approach can provide results similar to the IV technique, one advantage of using the former approach is that the former provides more precise estimates when an endogenous variable is non-linear (Wooldridge, 2010). The significance of the residuals in the CF approach may additionally indicate the presence of endogeneity in such models.

The main challenge in an IV estimation is to find appropriate instrument(s). We employ income which is recognised as a good instrument for consumption and have been employed in a number of important Engel curve studies (e.g., Banks et al., 1997; Blundell et al., 1998; Bhalotra and Attfield, 1998; Blundell et al., 2007). The reason is that income and consumption of households are highly correlated (strong instrument) while, in a two stage budgeting system, income has no direct effect on consumption shares (valid instrument). ${ }^{2}$

There are evidences of non-linearity in the use of energy with regard to consumption/income (e.g., Meier et al., 2013). For a number of reasons, detailed in the discussion of results, we may expect a U-shaped relation between energy (electricity/other energy) share and total consumption as depicted in Figure 1. The figure shows that when total consumption $(C)$ reaches at the threshold level $\left(C^{*}\right)$, energy $(\mathrm{Z})$ becomes luxury (expenditure elasticity, $\left.\xi_{d}>1\right)$ while it is necessary $\left(\xi_{d}<1\right)$ at values lower than the threshold. The threshold level of total consumption $\left(C^{*}\right)$, which is the turning point, can be identified using the Engel curve. Once we have some idea about the functional form of consumption from our semiparametric model, we can replace the nonparametric part in equation (1) with parametric specification to estimate a fully parametric Engel curve for each types of energy in our analysis.

\footnotetext{
${ }^{2}$ In a two stage budgeting system, given income, household first decide total consumption and then given total consumption, decides consumption for each category. The two stage budgeting system is commonly assumed in empirical Engel curve studies. See Liviatan (1961); Blundell (1988); Baker et al. (1989); Blundell et al. (1998, 2007), for detail.
} 


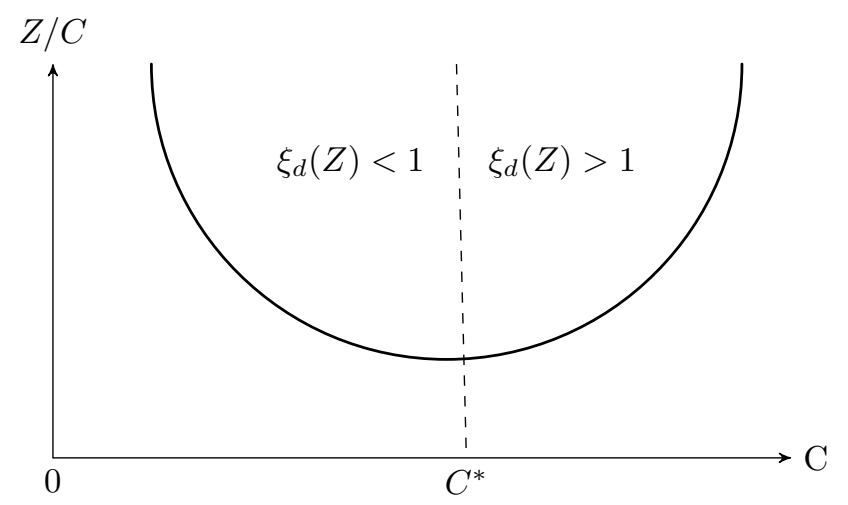

FIGURE 1: Movement of energy share with total consumption

\section{Data}

We use the 2010 round of Bangladesh Household Income and Expenditure Survey (HIES) data. The HIES is a cross-sectional survey repeated with an interval of 5 years and collects household and individual level data on income, consumption and other important socioeconomic and demographic variables. The survey relies on a two-stage stratified random sampling approach for the selection of households. The total number of surveyed households in 2010 round of HIES is 12,240 (Bangladesh Bureau of Statistics, 2012). Of those, we exclude a total of 407 observations which contain missing data on either income or energy consumption.

The HIES collects detail data on energy use, separately for electricity, kerosene, gas, coal, firewood, cow dung, jute stick, candle, matchbox and agricultural residue like rice bran, sugarcane bagasse and tree leaves. As the use of electricity becomes more important with growing income, we analyse the use of electricity in our investigation. On the other hand, use of other types of energy are quite low and we combine all of them (other energy) to conduct a separate analysis. Table 1 presents the means, standard deviations and some selected quantiles of the value of energy use, separately for electricity and other energy. The table demonstrates that nearly half of the selected households do not have any expenditure on electricity.

The zero expenditure of electricity for some households is due to the lack of electricity connections resulting from an inadequate infrastructure of electricity generation and transmission in Bangladesh. Not having an electricity connection can affect the pattern of 
TABLE 1: Summary statistics of household energy use (Taka/month)

\begin{tabular}{lrrrrrrrrrc}
\hline & Mean & SD & Min & Max & p5 & p25 & p50 & p75 & p95 & Obs \\
\hline Electricity & 258 & 243 & 20 & 8,000 & 70 & 130 & 200 & 300 & 650 & 6,515 \\
Other Energy & 489 & 287 & 4 & 6,280 & 180 & 325 & 450 & 575 & 987 & 11,800 \\
\hline
\end{tabular}

Note: On 17 December 2015,1 US\$ $\approx 78.50$ Taka (the local currency).

a household's energy use (Heltberg, 2004). Spending on energy use for those households, are the outcome of a constrained optimisation. However, an ambitious plan and huge programs for electricity generation have enabled the country to expand the access to electricity from $45 \%$ in 2008 to over $74 \%$ in 2015 (Planning Commission, 2015). This rising trend of access to electricity would imply that a large proportion of households in Bangladesh will start consuming electricity in the near future. Since our objective is to understand future energy consumption patterns, it appears reasonable to conduct the analysis on households with electricity connections.

Another reason of excluding households without electricity connection from our sample is the concern about potential reverse causality between electricity use and income. In particular, while income of a household explains whether it has an electricity connection or not, connectivity to a power source may also significantly affect income (Bridge et al., 2016). Our final sample includes a total of 6,515 households that have electricity connections at their residence.

Summary statistics for the dependent variables in our sample is presented at Table 2, showing that the mean expenditure on electricity use and other energy as a ratio of total consumption is $2.3 \%$ and $5.0 \%$, respectively. Households at the bottom 5 percentiles have a share of electricity use of $0.8 \%$ while families at the top 5 percentiles have a share of $4.8 \%$ indicating a good deal of variation in this spectrum. A similar pattern is also observed for the use of other energy. Interestingly, households without any electricity connection, who are excluded from our analysis sample, also have a similar expenditure share for other energy.

TABLE 2: Household energy use as share (\%) of total consumption

\begin{tabular}{|c|c|c|c|c|c|c|c|c|c|c|}
\hline & Mean & $\mathrm{SD}$ & Min & Max & $\mathrm{p} 5$ & $\mathrm{p} 25$ & $\mathrm{p} 50$ & $\mathrm{p} 75$ & p95 & $\mathrm{N}$ \\
\hline Electricity & 0.023 & 0.015 & 0.002 & 0.273 & 0.008 & 0.014 & 0.021 & 0.029 & 0.048 & 6,515 \\
\hline Other Energy & 0.050 & 0.028 & 0.000 & 0.347 & 0.014 & 0.031 & 0.045 & 0.065 & 0.101 & 6,515 \\
\hline
\end{tabular}


Table 3 indicates that mean proportion of both electricity and other energy use reduce with the increase in total consumption. However, while the mean consumption share of other energy is reduced to half as we move from the bottom to the top consumption quintile, it is only reduced by one-third for electricity. This indicates a faster increase in the use of electricity compared to the use of other energy.

TABLE 3: Mean household energy share (\%) by consumption quintiles

\begin{tabular}{lcccccc}
\hline & \multicolumn{5}{c}{ Quintile } & \multirow{2}{*}{ All } \\
\cline { 2 - 6 } & 1 & 2 & 3 & 4 & 5 & \\
\hline Electricity & 0.029 & 0.024 & 0.023 & 0.022 & 0.019 & 0.023 \\
Other Energy & 0.071 & 0.056 & 0.050 & 0.042 & 0.031 & 0.050 \\
\hline
\end{tabular}

Means and standard deviations of key independent variables in our model are presented in Table 4. A high variability of household income compared to household consumption is evident which can be due to the measurement error in income. This justifies our reliance on consumption, rather than income, for analysing the use of electricity and other energy.

\section{Results and discussion}

In order to examine the distribution of the effects of consumption over the quantiles of the dependent variables, electricity share and other energy share, we first perform quantile regressions. The plot of coefficients in Figure 2(a) indicates a negative effect of total consumption on electricity share. However, the effect becomes much stronger as we move along to higher shares of consumption, indicating a nonlinear relation between the two. We also observe a similar pattern for the other energy share although the slope of the plot is much steeper than that of electricity (Figure 2(b)).

Assuming other independent variables to be uncorrelated with total consumption allows us to employ a nonparametric (NP) technique to examine the relation of electricity share and other energy share with total consumption. The NP regression results again indicate a nonlinear relationship of total consumption with the expenditure shares of both types of energy use (Figure 3). However, the share of other energy appears to decrease at a faster rate than the share of electricity. 
a.Electricity

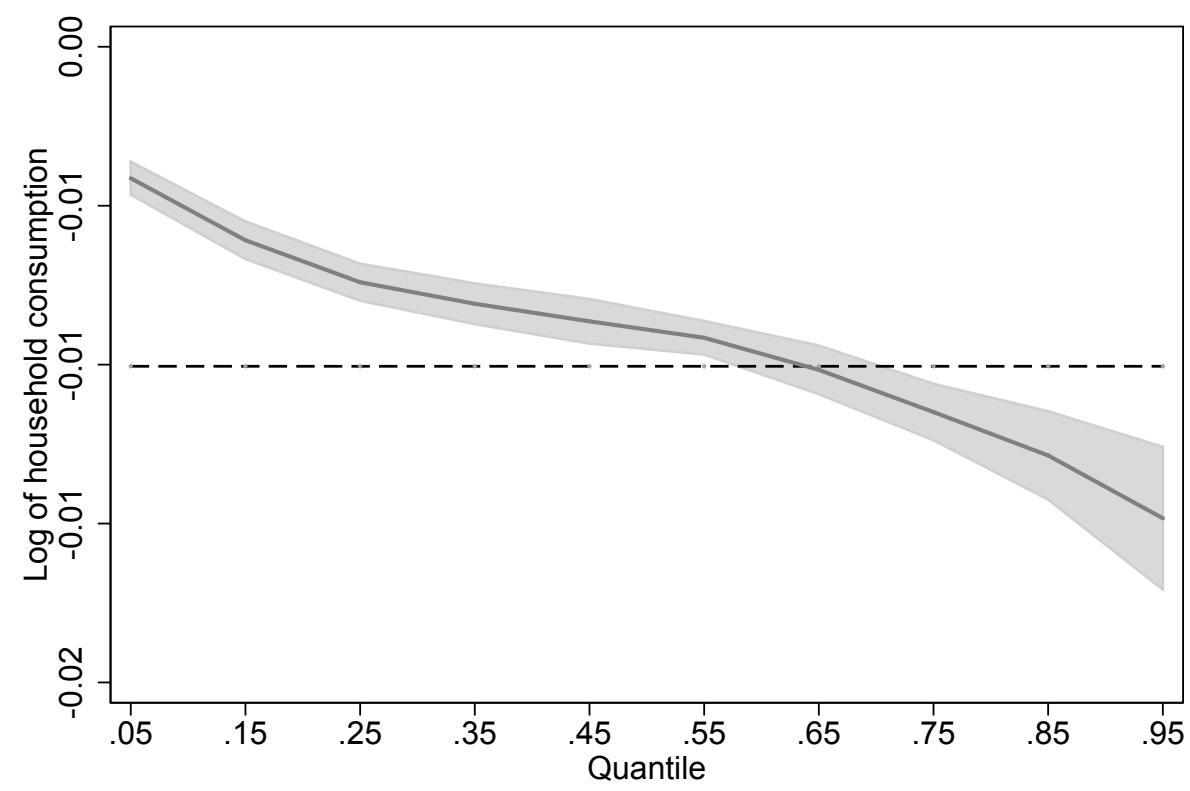

b.Other energy

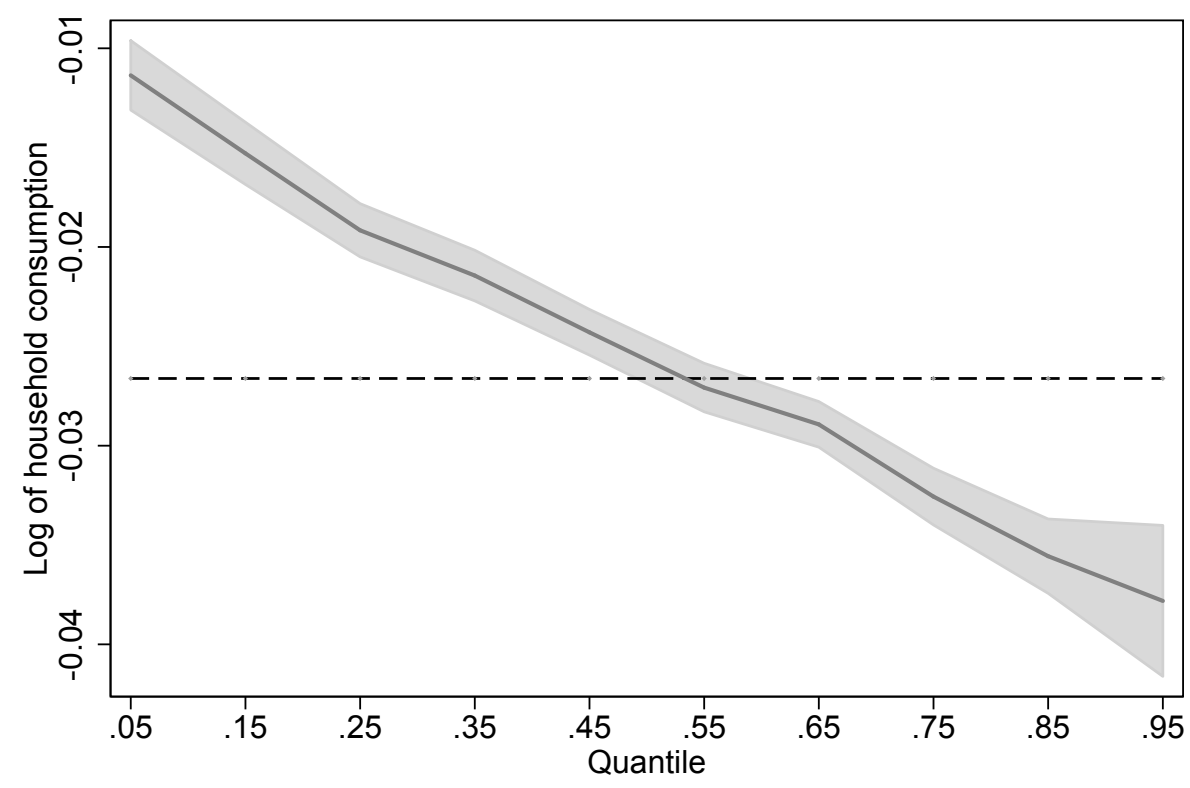

FIGURE 2: Coefficient plot of energy shares by quantiles (OLS estimates in $_{11}$ dashed lines) 
a. Electricity

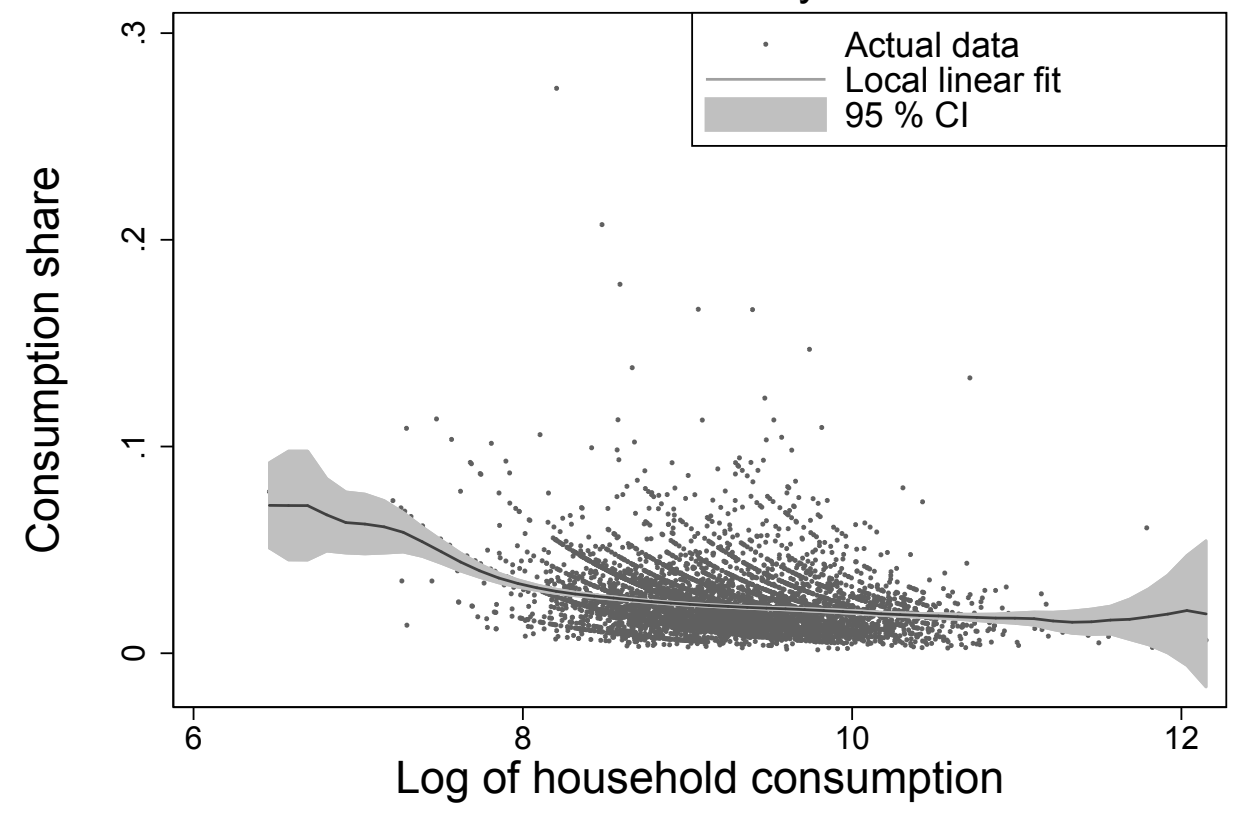

b. Other energy

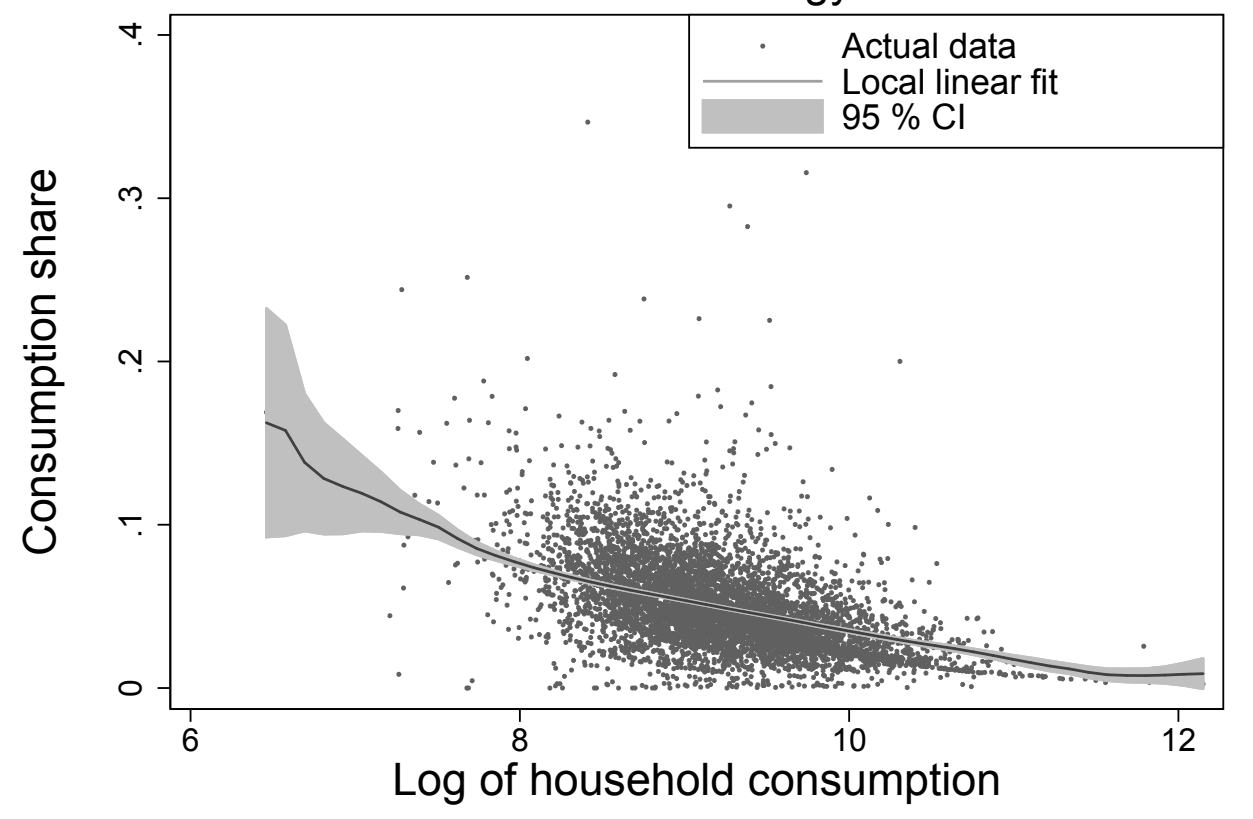

FIGURE 3: Nonparametric fit of energy shares 
TABLE 4: Summary statistics of independent variables

\begin{tabular}{|c|c|c|}
\hline & Mean & $\mathrm{SD}$ \\
\hline \multicolumn{3}{|l|}{ Finances } \\
\hline$\overline{\text { Household }}$ consumption (Taka/month) & 11,961 & 8,572 \\
\hline Household income (Taka/month) & 16,172 & 32,297 \\
\hline Consumption per capita (Taka/month) & 2,730 & 1,986 \\
\hline Income per capita (Taka/month) & 3,789 & 7,243 \\
\hline \multicolumn{3}{|l|}{ Demographics } \\
\hline Family size & 4.64 & 1.92 \\
\hline Adult member & 2.74 & 1.28 \\
\hline Child member & 1.90 & 1.32 \\
\hline Age of household head & 46.05 & 13.44 \\
\hline \multicolumn{3}{|l|}{ Education } \\
\hline Household head with no education & 0.41 & 0.49 \\
\hline Household head with primary education & 0.15 & 0.36 \\
\hline Household head with secondary education & 0.28 & 0.45 \\
\hline Household head with higher secondary education & 0.12 & 0.32 \\
\hline Household head with graduate degree & 0.04 & 0.19 \\
\hline Spouse of head with no education & 0.42 & 0.49 \\
\hline Spouse of head with primary education & 0.18 & 0.38 \\
\hline Spouse of head with secondary education & 0.33 & 0.47 \\
\hline Spouse of head with higher secondary education & 0.06 & 0.24 \\
\hline Spouse of head with graduate degree & 0.01 & 0.11 \\
\hline \multicolumn{3}{|l|}{ Other } \\
\hline Urban & 0.54 & 0.50 \\
\hline $\mathrm{N}$ & \multicolumn{2}{|c|}{6,515} \\
\hline
\end{tabular}

Since other independent variables can be correlated with consumption, a SP model would be more appropriate to investigate the relationship of energy use with consumption compared to a model that is NP in nature. We employ log of equivalised consumption (consumption from hereon) in our models and address the endogeneity in consumption using household income, as described in Section 2. The SP model estimates, presented in Table 5, indicate that key independent variables have significant impact on the use of both electricity and other energy. As we expect, education of household (head and spouse) as well as urban residency appear to have a positive effect on the energy consumption shares, particularly for electricity. Among other variables, significance of residuals from 
the first stage indicates that consumption can be endogenous in our model for electricity use.

TABLE 5: Semiparametric estimates from energy share model

\begin{tabular}{lcc}
\hline & Electricity & Other energy \\
\hline Family size & $-0.0008^{* * *}$ & -0.0003 \\
& $(0.0002)$ & $(0.0002)$ \\
Number of adults & $-0.0014^{* * *}$ & $-0.0046^{* * *}$ \\
& $(0.0003)$ & $(0.0004)$ \\
Household head's age & 0.0001 & 0.0001 \\
& $(0.0001)$ & $(0.0001)$ \\
Square of household & 0.0000 & -0.0000 \\
head's age & $(0.0000)$ & $(0.0000)$ \\
Household head has & 0.0002 & -0.0016 \\
primary education & $(0.0005)$ & $(0.0010)$ \\
Household head has & $0.0012^{* *}$ & $-0.0024^{* * *}$ \\
secondary education & $(0.0005)$ & $(0.0008)$ \\
Household head has & $0.0032^{* * *}$ & $-0.0018^{*}$ \\
higher secondary education & $(0.0009)$ & $(0.0011)$ \\
Household head has & $0.0023^{* *}$ & -0.0009 \\
graduate degree & $(0.0012)$ & $(0.0018)$ \\
Household head has & $0.0031^{*}$ & 0.0014 \\
other education & $(0.0018)$ & $(0.0048)$ \\
Spouse of head has & $0.0018^{* * *}$ & 0.0001 \\
primary education & $(0.0006)$ & $(0.0009)$ \\
Spouse of head has & $0.0033^{* * *}$ & $0.0015^{*}$ \\
secondary education & $(0.0005)$ & $(0.0009)$ \\
Spouse of head has & $0.0052^{* * *}$ & $0.0034^{* *}$ \\
higher secondary education & $(0.0011)$ & $(0.0015)$ \\
Spouse of head has & $0.0064^{* * *}$ & $0.0061^{* *}$ \\
graduate degree & $(0.0017)$ & $(0.0031)$ \\
Spouse of head has & $0.0131^{*}$ & 0.0094 \\
other education & $(0.0067)$ & $(0.0070)$ \\
Urban & $0.0054^{* * *}$ & $-0.0056^{* * *}$ \\
Residual & $(0.0005)$ & $(0.0012)$ \\
& $-0.0064^{* * *}$ & -0.0014 \\
Adjusted R ${ }^{2}$ & $(0.0011)$ & $(0.0017)$ \\
\hline Note: & 0.167 & 0.166 \\
& 6,515 & 6,515 \\
\hline & & \\
& & \\
& &
\end{tabular}

Note: We reported marginal effects from semiparametric models with (64) district fixed effects; clustered standard errors are reported in parentheses.

${ }^{*} \mathrm{p}<0.10,{ }^{* *} \mathrm{p}<0.05,{ }^{* * *} \mathrm{p}<0.01$.

Employing the estimates in Table 5, we calculate the partial out (of other independent variables) value of energy shares. Scatter plot of these values, together with their NP fit in 
Figure 4 again indicates a nonlinear relationship between energy shares (both electricity and other energy) and consumption. A formal test of the functional form, outlined in Hardle and Mammen (1993), rejects a model that is linear in consumption but cannot reject a quadratic specification for both types of energy use in our analysis. ${ }^{3}$

Since our test of SP models indicate towards a quadratic model for both types of energy use, we fit models that include both consumption and its square. Endogeneity in such models may occur due to both the linear and the quadratic term. Thus, in the first stage, we regress consumption on log of household income and its square and collect the residuals. We repeat the same process with squared consumption. Next, in the second stage, along with other covariates, we include residuals from previous regressions in the original model.

For the case of electricity share, the included residuals from the first stage regression are not significant individually but highly significant jointly. As a result, following the convention of the control function $(\mathrm{CF})$ approach, we only include the residuals which are generated by regressing consumption on the instruments and other covariates in the first stage. The significance of the residuals in the model indicates that while consumption can be endogenous in the model for electricity share, residuals generated through regressing the linear term are enough to control for such endogeneity. On the other hand, both the residuals from the first stage regressions are individually and jointly significant in our model for other energy share. Thus they indicate that controlling for the endogeneity of consumption requires using both income and its square as instruments in our model.

Our parametric model estimates indicate a negative marginal effect of consumption on both types of energy use (Table 6). In the model for electricity, consumption is only significant at the $10 \%$ level when all the control variables are dropped (Column 1). However, as we add controls variables (Column 2) and district fixed effects (Column 3), the coefficient becomes highly significant. In all cases residuals for the first stage remains highly significant, again validating our guess about the endogeneity of consumption in our model. While the pattern is similar for other energy, a higher marginal value of the coefficient of consumption reflects the fact that as income grows households reduce their

\footnotetext{
${ }^{3}$ All tests in our analysis are conducted at the $5 \%$ level of significance. See Appendix, Table A.1 for the p-values from Hardle and Mammen (1993) test.
} 
a. Electricity

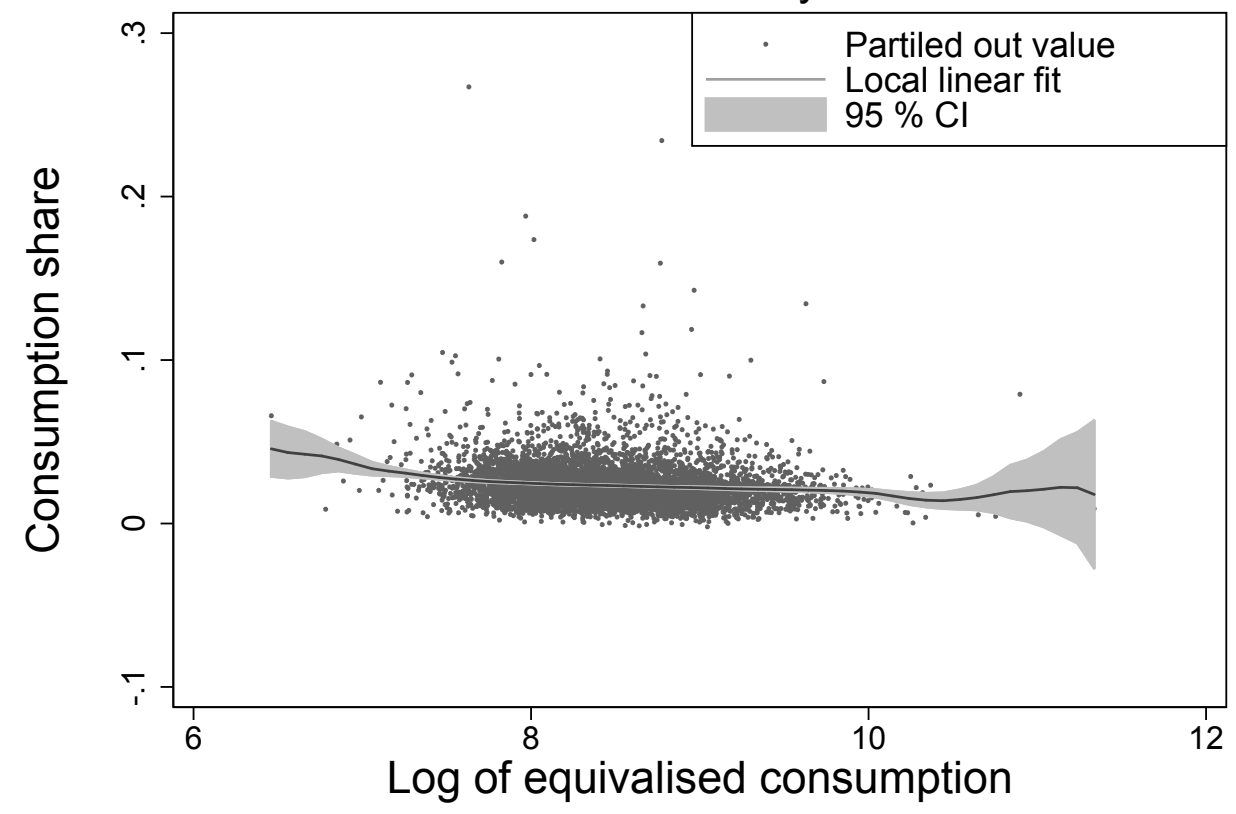

b. Other energy

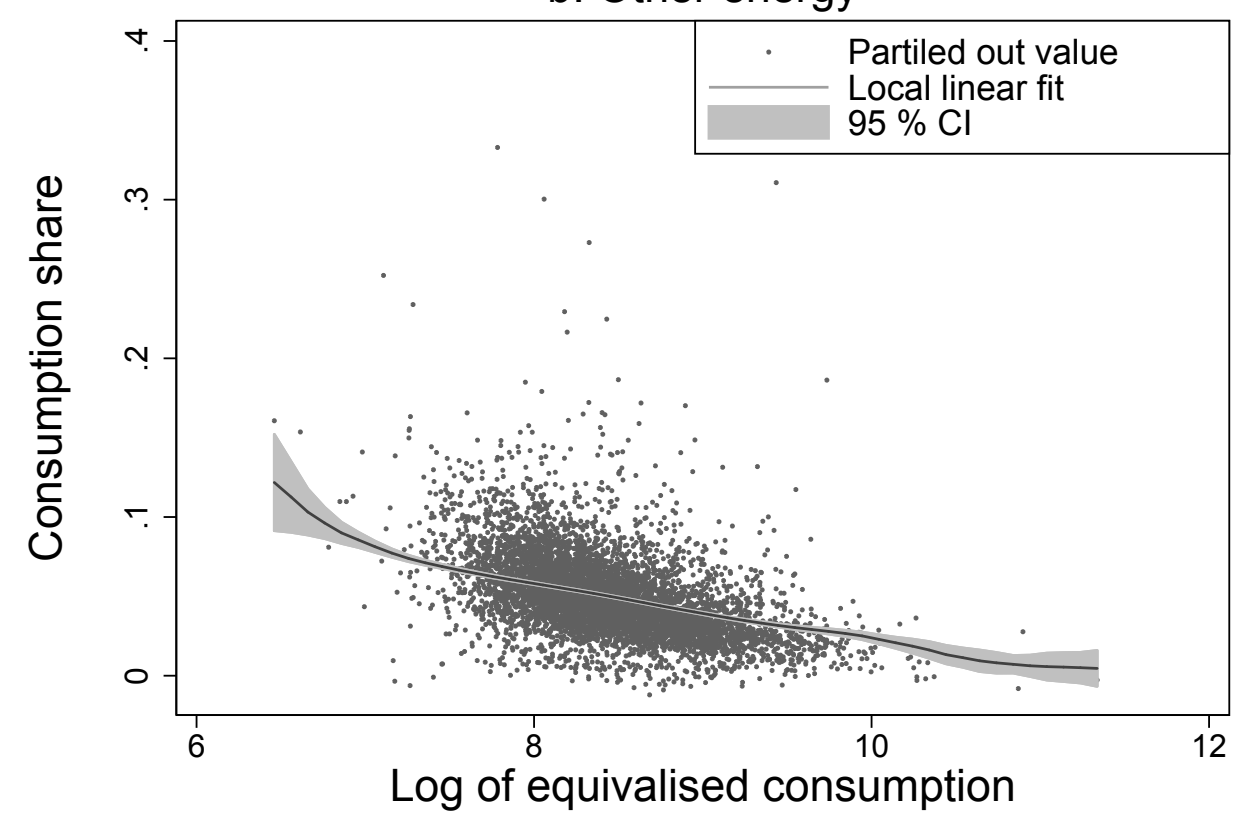

FIguRE 4: Nonparametric fit of partialed out energy shares 
consumption share of other energy at a faster rate compared to the share of electricity. Our results indicate a quadratic EEC for both electricity and other energy and are largely similar to earlier studies. For example, Banks et al. (1997) employ a nonlinear model in expenditure and find a quadratic Engel curve for fuel. Barnes et al. (2011) observe a similar pattern for energy (all combined) in Bangladesh.

Estimates of other important variables from the preferred model (Column 3 and 6, Table 6) indicate effects that are largely similar to that of the semiparametric models. For example, household head's age and head/spouse's education have positive impact on energy shares. This can be due to the fact that household's education is usually associated with their socioeconomic status which again can be related with the ownership of energy intensive items like electronics and appliances. Among other important variables, urban households consume more of electricity and less of other energy than rural households. Interestingly, the two quantities are roughly similar indicating that urban households substitute electricity for other energy. We see that coefficients of family size are significant in Table 6 but negative for electricity use and positive for other energy use. Since we have already employed equivalised consumption, this implies that there is an economy of scale in the consumption of electricity but a diseconomy of scale in the consumption of other energy. Thus our results indicate differences in the economy of scale in the consumption of the two types of energy.

The individual coefficient of consumption and its square are presented in Table 7 for both types of energy use in our analysis. A negative coefficient for consumption and a positive coefficient for its square for electricity use imply a U-shaped relation of its share with consumption. The coefficients for the share of other energy indicate a similar pattern. Thus, as consumption increases households initially increase their consumption of energy less than proportionally. However, after reaching a threshold, energy consumption increase more than proportionally as consumption continues to rise. The close relation between consumption and income indicates a similar relationship with income.

The observed pattern of energy demand is plausible for low-income countries where people can have unmet demands for necessary goods and services (e.g., food, housing and education) at low incomes. As their incomes rise, they spend their additional incomes 
TABLE 6: OLS estimates from quadratic energy share model with equivalised consumption

\begin{tabular}{|c|c|c|c|c|c|c|}
\hline & \multicolumn{3}{|c|}{ Electricity } & \multicolumn{3}{|c|}{ Other energy } \\
\hline & (1) & $(2)$ & (3) & (4) & (5) & (6) \\
\hline $\begin{array}{l}\text { Log of equivalized } \\
\text { consumption }\end{array}$ & $\begin{array}{l}-0.0016^{*} \\
(0.0008)\end{array}$ & $\begin{array}{c}-0.0055^{* * *} \\
(0.0010)\end{array}$ & $\begin{array}{c}-0.0044^{* * *} \\
(0.0008)\end{array}$ & $\begin{array}{c}-0.0279^{* * *} \\
(0.0018)\end{array}$ & $\begin{array}{c}-0.0198^{* * *} \\
(0.0030)\end{array}$ & $\begin{array}{c}-0.0406^{* * *} \\
(0.0031)\end{array}$ \\
\hline Age of household head & & $\begin{array}{c}0.0001^{* * *} \\
(0.0000)\end{array}$ & $\begin{array}{c}0.0001^{* * *} \\
(0.0000)\end{array}$ & & $\begin{array}{c}0.0001 \\
(0.0000)\end{array}$ & $\begin{array}{c}0.0001^{* * *} \\
(0.0000)\end{array}$ \\
\hline Family size & & $\begin{array}{c}-0.0010^{* * *} \\
(0.0002)\end{array}$ & $\begin{array}{c}-0.0013^{* * *} \\
(0.0002)\end{array}$ & & $\begin{array}{c}-0.0015^{* * *} \\
(0.0004)\end{array}$ & $\begin{array}{l}0.0010^{* *} \\
(0.0004)\end{array}$ \\
\hline Number of adults & & $\begin{array}{c}-0.0007^{* * *} \\
(0.0003)\end{array}$ & $\begin{array}{l}-0.0004 \\
(0.0003)\end{array}$ & & $\begin{array}{c}-0.0030^{* * *} \\
(0.0006)\end{array}$ & $\begin{array}{c}-0.0057^{* * *} \\
(0.0005)\end{array}$ \\
\hline Household head has & & -0.0000 & -0.0001 & & -0.0006 & -0.0003 \\
\hline primary education & & $(0.0006)$ & $(0.0006)$ & & $(0.0013)$ & $(0.0011)$ \\
\hline Household head has & & 0.0005 & 0.0005 & & $-0.0032^{* * *}$ & -0.0003 \\
\hline secondary education & & $(0.0006)$ & $(0.0006)$ & & $(0.0009)$ & $(0.0008)$ \\
\hline Household head has & & $0.0024^{* * *}$ & $0.0021^{* *}$ & & $-0.0035^{* *}$ & 0.0006 \\
\hline higher secondary education & & $(0.0009)$ & $(0.0009)$ & & $(0.0014)$ & $(0.0012)$ \\
\hline Household head has & & 0.0015 & 0.0011 & & $-0.0034^{*}$ & 0.0012 \\
\hline graduate degree & & $(0.0014)$ & $(0.0013)$ & & $(0.0021)$ & $(0.0019)$ \\
\hline Household head has & & 0.0034 & 0.0025 & & -0.0009 & 0.0031 \\
\hline other education & & $(0.0021)$ & $(0.0018)$ & & $(0.0058)$ & $(0.0045)$ \\
\hline Spouse of head has & & $0.0013^{* *}$ & $0.0013^{* *}$ & & -0.0011 & $0.0021^{* *}$ \\
\hline primary education & & $(0.0006)$ & $(0.0006)$ & & $(0.0010)$ & $(0.0010)$ \\
\hline Spouse of head has & & $0.0023^{* * *}$ & $0.0023^{* * *}$ & & -0.0007 & $0.0037^{* * *}$ \\
\hline secondary education & & $(0.0006)$ & $(0.0005)$ & & $(0.0010)$ & $(0.0010)$ \\
\hline Spouse of head has & & $0.0041^{* * *}$ & $0.0036^{* * *}$ & & 0.0002 & $0.0041^{* * *}$ \\
\hline higher secondary education & & $(0.0012)$ & $(0.0011)$ & & $(0.0017)$ & $(0.0015)$ \\
\hline Spouse of head has & & $0.0054^{* * *}$ & $0.0040^{* *}$ & & 0.0029 & 0.0012 \\
\hline graduate degree & & $(0.0020)$ & $(0.0018)$ & & $(0.0033)$ & $(0.0032)$ \\
\hline Spouse of head has & & 0.0094 & 0.0089 & & 0.0013 & 0.0086 \\
\hline other education & & $(0.0067)$ & $(0.0070)$ & & $(0.0066)$ & $(0.0069)$ \\
\hline Urban & & $\begin{array}{c}0.0053^{* * *} \\
(0.0007)\end{array}$ & $\begin{array}{c}0.0050^{* * *} \\
(0.0007)\end{array}$ & & $\begin{array}{c}-0.0062^{* * *} \\
(0.0013)\end{array}$ & $\begin{array}{c}-0.0050^{* * *} \\
(0.0013)\end{array}$ \\
\hline Residual 1 & $\begin{array}{c}-0.0095^{* * *} \\
(0.0011)\end{array}$ & $\begin{array}{c}-0.0054^{* * *} \\
(0.0013)\end{array}$ & $\begin{array}{c}-0.0066^{* * *} \\
(0.0011)\end{array}$ & $\begin{array}{l}0.1483^{* *} \\
(0.0689)\end{array}$ & $\begin{array}{l}-0.1284 \\
(0.0976)\end{array}$ & $\begin{array}{c}0.4752^{* * *} \\
(0.1005)\end{array}$ \\
\hline Residual 2 & & & & $\begin{array}{c}-0.0088^{* *} \\
(0.0040)\end{array}$ & $\begin{array}{c}0.0071 \\
(0.0056)\end{array}$ & $\begin{array}{c}-0.0274^{* * *} \\
(0.0058)\end{array}$ \\
\hline Constant & $\begin{array}{c}0.2252^{* * *} \\
(0.0551)\end{array}$ & $\begin{array}{c}0.1795^{* * *} \\
(0.0516)\end{array}$ & $\begin{array}{c}0.1834^{* * *} \\
(0.0556)\end{array}$ & $\begin{array}{c}1.2534^{* * *} \\
(0.2837)\end{array}$ & $\begin{array}{c}0.0748 \\
(0.4129)\end{array}$ & $\begin{array}{c}2.6826^{* * *} \\
(0.4289)\end{array}$ \\
\hline District fixed effects (64) & No & No & Yes & No & No & Yes \\
\hline Adjusted $\mathrm{R}^{2}$ & 0.07 & 0.14 & 0.20 & 0.22 & 0.27 & 0.35 \\
\hline $\mathrm{N}$ & 6,515 & 6,515 & 6,515 & 6,515 & 6,515 & 6,515 \\
\hline
\end{tabular}

Note: We reported marginal effects from OLS estimates; bootstrapped clustered standard errors are reported in parentheses.

${ }^{*} \mathrm{p}<0.10,{ }^{* *} \mathrm{p}<0.05,{ }^{* * *} \mathrm{p}<0.01$. 
on these necessary goods and services more than proportionally, resulting in a reduction in the share of other types of consumption including energy (Hasan, 2016). When income increases enough, people may increase spending more than proportionally on categories like energy. This may result in a U-shaped relation between energy share and consumption. Furthermore, for electricity, such effect can be stronger as people at higher incomes usually buy electronic items (e.g., phone, TV and computer) and appliances (e.g., refrigerator, air conditioner and fan) that heavily rely on electricity.

TABLE 7: OLS Estimates of consumption coefficients

\begin{tabular}{|c|c|c|c|c|c|c|}
\hline & \multicolumn{2}{|c|}{ Equivalised } & \multicolumn{2}{|c|}{ Household } & \multicolumn{2}{|c|}{ Per capita } \\
\hline & Electricity & $\begin{array}{l}\text { Other } \\
\text { energy }\end{array}$ & Electricity & $\begin{array}{l}\text { Other } \\
\text { energy }\end{array}$ & Electricity & $\begin{array}{l}\text { Other } \\
\text { energy }\end{array}$ \\
\hline Linear term & $\begin{array}{c}-0.0333^{* * *} \\
(0.0129)\end{array}$ & $\begin{array}{c}-0.5846^{* * *} \\
(0.0999)\end{array}$ & $\begin{array}{c}-0.0504^{* * *} \\
(0.0109)\end{array}$ & $\begin{array}{c}-0.2817^{* * *} \\
(0.0517)\end{array}$ & $\begin{array}{c}-0.0607^{* * *} \\
(0.0114)\end{array}$ & $\begin{array}{c}-0.3129^{* * *} \\
(0.0715)\end{array}$ \\
\hline Quadratic term & $\begin{array}{l}0.0017^{* *} \\
(0.0008)\end{array}$ & $\begin{array}{c}0.0322^{* * *} \\
(0.0058)\end{array}$ & $\begin{array}{c}0.0025^{* * *} \\
(0.0006)\end{array}$ & $\begin{array}{c}0.0135^{* * *} \\
(0.0027)\end{array}$ & $\begin{array}{c}0.0029^{* * *} \\
(0.0006)\end{array}$ & $\begin{array}{c}0.0180^{* * *} \\
(0.0045)\end{array}$ \\
\hline Adjusted $\mathrm{R}^{2}$ & 0.202 & 0.350 & 0.220 & 0.364 & 0.216 & 0.337 \\
\hline $\mathrm{N}$ & 6,515 & 6,515 & 6,515 & 6,515 & 6,515 & 6,515 \\
\hline
\end{tabular}

Note: We report OLS estimates with CF approach which include (64) district fixed effects; bootstrapped clustered standard errors are reported in parentheses.

${ }^{*} \mathrm{p}<0.10,{ }^{* *} \mathrm{p}<0.05,{ }^{* * *} \mathrm{p}<0.01$.

Our results are robust to a number of modifications in model specifications. We obtain similar results as we repeat the analysis either with the total household consumption or the per capita consumption (Tables 7, A.2 and A.3). We also find similar results when we employ consumption that is equivalised by either the OECD or the square root of family size (SRFS) scale (Tables A.4 and A.5). Finally, a model that is cubic in equivalised consumption also indicates a similar marginal effect of consumption on the share of both types of energy use.

To make our analysis useful for policy formulation, we plot the predicted expenditure shares of energy use and their quadratic fit against total household consumption (Figure 5). It indicates that the consumption share of electricity exhibits a U-shaped pattern. On the other hand, we observe a rapid reduction in the share of other energy which does not pick up with income and therefore more closely resembles a flipped J-shaped pattern in its movement with total consumption. 
a. Electricity

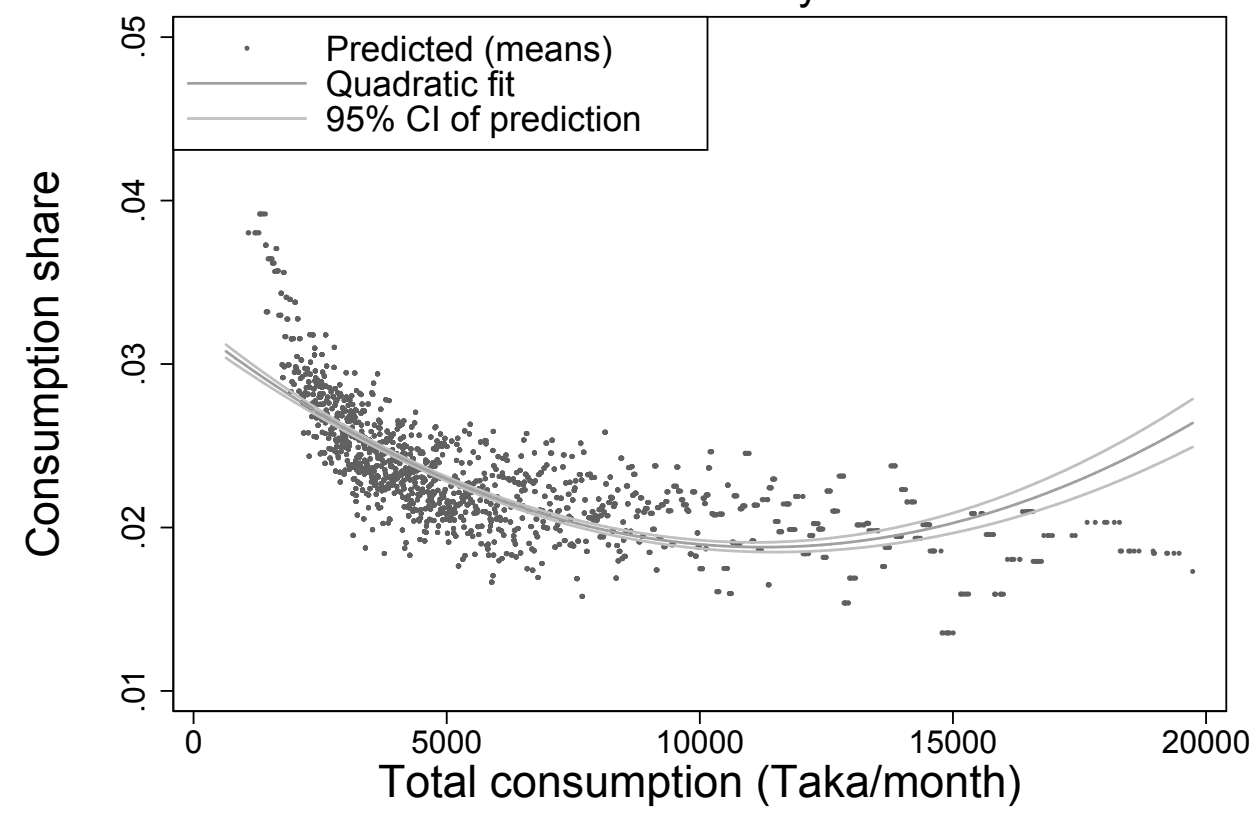

b. Other energy

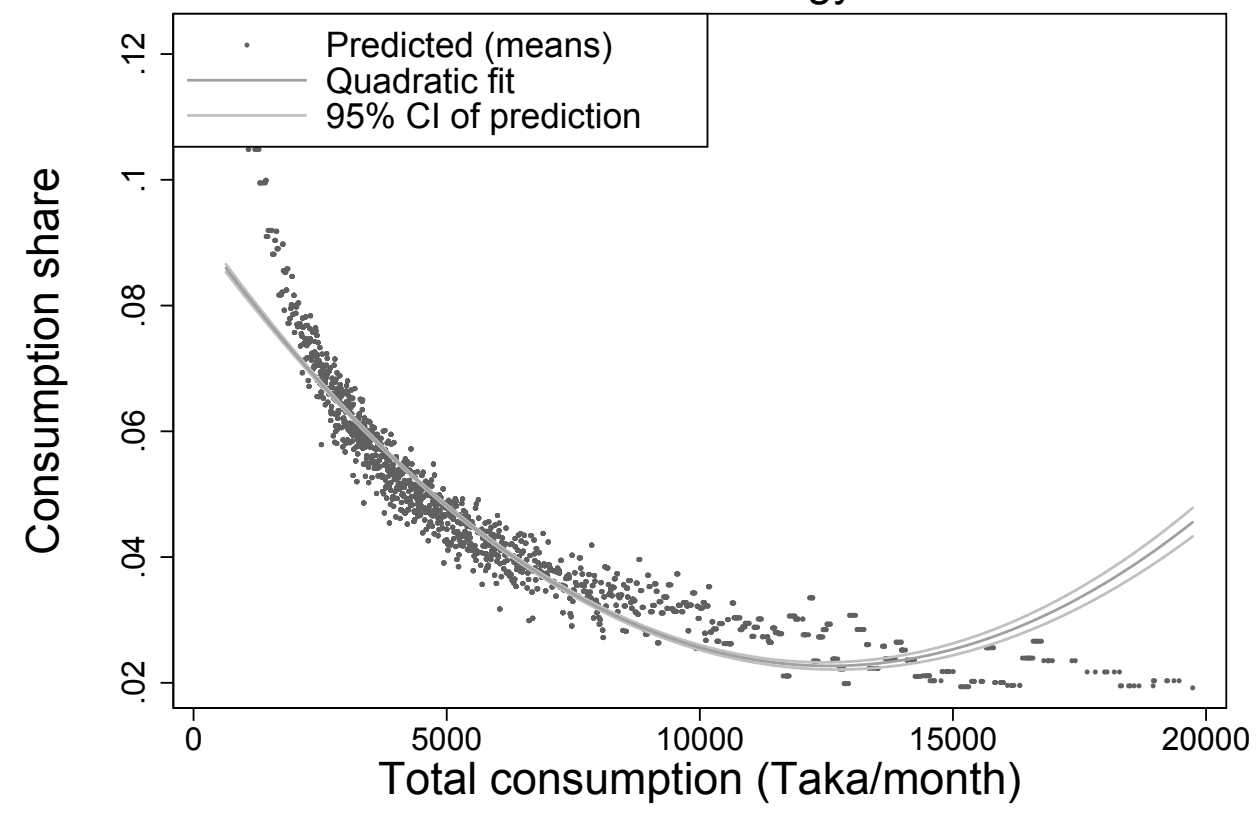

Figure 5: Predicted energy share and fitted line 
Next, we employ the earlier model estimates to find the mean consumption (with $95 \%$ confidence intervals) at which the shares of energy use start to increase (Table 8). Based on the current consumption and the growth rate of the economy, we also report the number of years required to reach at the turning point. Our analysis indicates that, for the country, it would require 17 additional years for electricity consumption to be at a minimum (turning point) as a proportion of total consumption, which would increase thereafter. The needed time is much lower (7 years) for other energy.

Our results, consistent with other empirical studies indicate that there are often economies of scale in family size as well as number of children in the household (Hasan, 2016). Furthermore, demographic structure is expected to change with time and the level of development. In such circumstances, analyses with equivalised consumption appear to be more appropriate for analysing energy use. As a result, in calculating the number of years to reach the turning point, we emphasise on models that employ equivalised consumption.

\section{Conclusion}

This study investigates the household energy consumption pattern in Bangladesh. We employ the 2010 round of Household Income and Expenditure Survey data and select households who have the electricity connection at their residences. Based on a wide range of empirical specifications we find that the consumption share of both electricity and other energy use changes in a nonlinear U-shaped fashion as total household consumption rises. This indicates that as income increases households initially increase their consumption of energy less than proportionally. However, after reaching a threshold, energy consumption increase more than proportionally as income continues to rise. We also provide a socio-demographic snapshot of energy consumption as Bangladesh makes transition from a low- to middle-income country. Our analyses predict that the energy consumption of urban, educated and smaller households in Bangladesh will grow more than proportionally compared to their counterparts.

The findings in our analysis can provide important inputs to the demand side management of energy, particularly for electricity, in Bangladesh. For example, identification of the turning points can give us some idea about the income level after which the de- 
TABLE 8: Turning points of energy shares (in Taka)

\begin{tabular}{|c|c|c|c|c|c|c|}
\hline \multirow[b]{2}{*}{ With respect to } & \multicolumn{3}{|c|}{ Electricity } & \multicolumn{3}{|c|}{ Other energy } \\
\hline & $\begin{array}{l}\text { Lower } \\
\text { bound }\end{array}$ & Mean & $\begin{array}{l}\text { Upper } \\
\text { bound }\end{array}$ & $\begin{array}{l}\text { Lower } \\
\text { bound }\end{array}$ & Mean & $\begin{array}{l}\text { bound } \\
\text { bound }\end{array}$ \\
\hline $\begin{array}{l}\text { Equivalised consumption } \\
\text { Years required }\end{array}$ & 6,514 & $\begin{array}{l}16,650 \\
{[16.77]}\end{array}$ & 42,561 & 7,629 & $\begin{array}{l}8,770 \\
{[7.30]}\end{array}$ & 10,081 \\
\hline \multicolumn{7}{|c|}{ Implied consumption levels for households with: } \\
\hline 1 adult \& 0 child & 6,514 & 16,650 & 42,561 & 7,629 & 8,770 & 10,081 \\
\hline 1 adult \& 1 child & 7,316 & 18,702 & 47,805 & 8,569 & 9,850 & 11,323 \\
\hline 1 adult \& 2 child & 8,089 & 20,677 & 52,853 & 9,474 & 10,890 & 12,518 \\
\hline 1 adult \& 3 child & 8,836 & 22,587 & 57,738 & 10,350 & 11,897 & 13,675 \\
\hline 1 adult \& 4 child & 9,562 & 24,443 & 62,480 & 11,200 & 12,874 & 14,798 \\
\hline 2 adult \& 0 child & 10,879 & 27,809 & 71,085 & 12,742 & 14,647 & 16,836 \\
\hline 2 adult \& 1 child & 11,556 & 29,540 & 75,508 & 13,535 & 15,558 & 17,884 \\
\hline 2 adult \& 2 child & 12,219 & 31,235 & 79,843 & 14,312 & 16,451 & 18,911 \\
\hline 2 adult \& 3 child & 12,870 & 32,899 & 84,096 & 15,074 & 17,328 & 19,918 \\
\hline 2 adult \& 4 child & 13,510 & 34,534 & 88,274 & 15,823 & 18,189 & 20,908 \\
\hline 3 adult \& 0 child & 14,686 & 37,540 & 95,959 & 17,201 & 19,772 & 22,728 \\
\hline 3 adult \& 1 child & 15,297 & 39,103 & 99,954 & 17,917 & 20,595 & 23,674 \\
\hline 3 adult \& 2 child & 15,900 & 40,644 & 103,893 & 18,623 & 21,407 & 24,607 \\
\hline 3 adult \& 3 child & 16,495 & 42,165 & 107,781 & 19,320 & 22,208 & 25,528 \\
\hline 3 adult \& 4 child & 17,083 & 43,667 & 111,620 & 20,008 & 22,999 & 26,437 \\
\hline 4 adult \& 0 child & 18,170 & 46,446 & 118,724 & 21,282 & 24,463 & 28,120 \\
\hline 4 adult \& 1 child & 18,738 & 47,899 & 122,438 & 21,947 & 25,228 & 28,999 \\
\hline 4 adult \& 2 child & 19,301 & 49,336 & 126,112 & 22,606 & 25,985 & 29,869 \\
\hline 4 adult \& 3 child & 19,857 & 50,759 & 129,750 & 23,258 & 26,735 & 30,731 \\
\hline 4 adult \& 4 child & 20,409 & 52,168 & 133,351 & 23,904 & 27,477 & 31,584 \\
\hline
\end{tabular}

Notes: 1. Turning points and upper and lower limits (95\% CI) are based on estimates in Table 6 and Appendix Tables A.2 and A.3.

2. Values correspond to the exponentials of model estimates, as consumption enters into the model in logarithmic form.

3. Numbers inside the square brackets report the average years required to reach the turning point, given the country's present growth scenario $(\approx 7 \% /$ year $)$ and assuming no change in the distribution of household consumption over time.

mand for electricity and other energy would increase rapidly in the country. Thus the turning point estimates can be particularly useful for future planning in expanding the access to electricity and other energy sources. The analysis also provide insights on how the supply of other energy can assist in managing acute energy shortage in the country.

World energy consumption is expected to rise by $48 \%$ between 2012 and 2040 . Since economic growth is a key determinant of the rising energy demand, the fastest rates of energy growths are projected for the emerging countries where combined GDP would increase annually by $4.2 \%$ from 2012 to 2040 , compared to a global rate $3.3 \%$ per year. 
The growth is estimated to be much higher for electricity (69\%), for the same reference period. Again, the significant growth in electricity generation is expected to take place in the developing nations where rising living standards would increase demand for home appliances and electronic devices as well for commercial services, including hospitals, schools, office buildings and shopping malls (U.S. Energy Information Administration, 2016). This study may assist in the estimation of energy Engel curves for other emerging countries. Doing so can improve their forecasts of future energy demand including electricity in the likely case of a changing demographic structure in those economies.

A rise in global energy demand would also be accompanied by a significant switching towards modern energy. Unfortunately, despite intensified efforts in many countries, hundreds of millions of people will be left without basic energy services even in 2040 (International Energy Agency, 2016). Government may consider tariffs and subsidies to facilitate access to affordable electricity while minimising price distortions (World Bank, 2010). This study can be useful to indicate the share of burden borne by the lowincome people resulting from a tax imposed on energy and related welfare implication in developing countries.

\section{Acknowledgements}

We thank Syed M. Ahsan and participants of the 50th Annual Conference of the Canadian Economics Association (CEA) for providing useful comments on an earlier draft. 


\section{References}

I. Almås. International income inequality: Measuring PPP bias by estimating Engel curves for food. The American Economic Review, 102(2):1093-1117, 2012.

V. Assimakopoulos and H. Domenikos. Consumption preferences structure of Greek households. Energy economics, 13(3):163-167, 1991.

P. Baker, R. Blundell, and J. Micklewright. Modelling household energy expenditures using micro-data. The Economic Journal, 99(397):720-738, 1989.

Bangladesh Bureau of Statistics. Report of the Household Income and Expenditure Survey - 2010. Final report, Bangladesh Bureau of Statistics, April 2012.

J. Banks, R. Blundell, and A. Lewbel. Quadratic Engel curves and consumer demand. The Review of Economics and Statistics, 79(4):527-539, 1997.

D. F. Barnes, S. R. Khandker, and H. A. Samad. Energy poverty in rural Bangladesh. Energy Policy, 39(2):894-904, 2011

S. Bhalotra and C. Attfield. Intrahousehold resource allocation in rural Pakistan: A semiparametric analysis. Journal of Applied Econometrics, 13(5):463-480, 1998.

R. Blundell. Consumer behaviour: Theory and empirical evidence-A survey. The Economic Journal, 98(389):16-65, 1988.

R. Blundell, A. Duncan, and K. Pendakur. Semiparametric estimation and consumer demand. Journal of Applied Econometrics, 13(5):435-461, 1998.

R. Blundell, X. Chen, and D. Kristensen. Semi-nonparametric IV estimation of shape-invariant Engel curves. Econometrica, 75(6):1613-1669, 2007.

B. A. Bridge, D. Adhikari, and M. Fontenla. Household-level effects of electricity on income. Energy Economics, 58:222-228, 2016.

P. J. Burke and Z. Csereklyei. Understanding the energy-GDP elasticity: A sectoral approach. Energy Economics, 58:199-210, 2016.

A. Das, A. A. McFarlane, and M. Chowdhury. The dynamics of natural gas consumption and GDP in Bangladesh. Renewable and Sustainable Energy Reviews, 22:269-274, 2013.

A. Deaton. The Analysis of Household Surveys: A Microeconometric Approach to Development Policy. World Bank, Washington D.C, USA, 1997.

A. Deaton and J. Muellbauer. Economics and Consumer Behaviour. Cambridge University Press, Cambridge, USA, 1st edition, 1980.

J. Engel and A. Kneip. Recent approaches to estimating Engel curves. Journal of Economics, 63(2): $187-212,1996$.

Finance Division. Bangladesh Economic Review. Annual review, Ministry of Finance, Bangladesh Government, June 2016. Available from: http://www.mof.gov.bd/en/index.php?option=com_content\&view $=$ article\&id=367\&Itemid=1 [Accessed: 29 January 2017].

H. Gundimeda and G. Köhlin. Fuel demand elasticities for energy and environmental policies: Indian sample survey evidence. Energy Economics, 30(2):517-546, 2008. 
W. Hardle and E. Mammen. Comparing nonparametric versus parametric regression fits. The Annals of Statistics, 21(4):1926-1947, 1993.

S. A. Hasan. Engel curves and equivalence scales for Bangladesh. Journal of the Asia Pacific Economy, 21(2):301-315, 2016.

R. Heltberg. Fuel switching: Evidence from eight developing countries. Energy economics, 26(5):869-887, 2004.

International Energy Agency. World Energy Outlook 2016. Annual publication, The International Energy Agency (IEA), November 2016. Available from: http://www.iea.org/bookshop/720World_Energy_Outlook_2016 [Accessed: 29 January 2017].

D. Ironmonger, I. Manning, and T. Van Hoa. Longitudinal working models: Estimates of household energy consumption in Australia. Energy Economics, 6(1):41-46, 1984.

A. Lewbel. Engel curves. In S. N. Durlauf, L. Blume, and L. E., editors, The New Palgrave Dictionary of Economics, chapter 1, pages 1-7. Palgrave Macmillan Basingstoke, NY, 2 edition, 2008.

N. Liviatan. Errors in variables and Engel curve analysis. Econometrica, 29(3):336-362, 1961.

H. Meier, T. Jamasb, and L. Orea. Necessity or luxury good? Household energy spending and income in Britain 1991-2007. The Energy Journal, 34(4):109-129, 2013.

P. Mozumder and A. Marathe. Causality relationship between electricity consumption and GDP in Bangladesh. Energy Policy, 35(1):395-402, 2007.

M. K. Mujeri, T. T. Chowdhury, and S. Shahana. Energy sector in Bangladesh: An agenda for reforms. GSI Report, 2014. Available from: https://www.iisd.org/sites/default/files/publications/energy_ sector_bangladesh.pdf [Accessed: 25 January 2017].

F. H. Navajas. Engel curves, household characteristics and low-user tariff schemes in natural gas. Energy Economics, 31(1):162-168, 2009.

W. K. Newey, J. L. Powell, and F. Vella. Nonparametric estimation of triangular simultaneous equations models. Econometrica, 67(3):565-603, 1999.

B. P. Paul and G. Uddin. Energy and output dynamics in Bangladesh. Energy Economics, 33(3) 480-487, 2011.

Planning Commission. Seventh Five Year Plan (FY2016 - FY2020): Accelerating Growth, Empowering Citizens. Final version, Planning Commission, Bangladesh Government, December 2015.

S. Ruhul, S. Rafiq, and A. K. Hassan. Causality and dynamics of energy consumption and output: Evidence from non-oecd asian countries. Journal of Economic Development, 33(2):1-26, 2008.

R. Summers. A note on least squares bias in household expenditure analysis. Discussion Paper 29, Cowles Foundation for Research in Economics, Yale University, 1957.

U.S. Energy Information Administration. International Energy Outlook 2016. Annual publication, U.S. Energy Information Administration, May 2016. Available from: www.eia.gov/forecasts/ieo/pdf/ 0484(2016).pdf [Accessed: 29 January 2017].

J. M. Wooldridge. Econometric Analysis of Cross Section and Panel Data. MIT Press Books. The MIT Press, 1 edition, 2010 . 
World Bank. Addressing the electricity access gap. Background paper for the world bank group energy sector strategy, World Bank, Washington, D.C., 2010. Available from: http://siteresources. worldbank.org/EXTESC/Resources/Addressing_the_Electricity_Access_Gap.pdf [Accessed: 29 January 2017].

World Bank. Bangladesh - Country snapshot. Country report, World Bank, Washington, D.C., 2016. Available from: http://documents.worldbank.org/curated/en/654391476782032287/BangladeshCountry-snapshot [Accessed: 25 January 2017].

World Bank. Bangladesh: Ensuring a reliable and quality energy supply. Media Report, 2017. Available from: http://www.worldbank.org/en/results/2016/10/07/bangladesh-ensuring-a-reliable-and-quality -energy-supply [Accessed: 25 January 2017].

H. Youn and H. J. Jin. The effects of progressive pricing on household electricity use. Journal of Policy Modeling, 38(6):1078-1088, 2016. 


\section{Appendix A: Tables}

TABLE A.1: Hardle and Mammen (1993) test results

\begin{tabular}{lcc}
\hline \multirow{2}{*}{ Consumption shares } & \multicolumn{2}{c}{$\mathrm{p}$-values } \\
\cline { 2 - 3 } & Linear model & Quadratic model \\
\hline Electricity & 0.02 & 0.14 \\
Other energy & 0.00 & 0.53 \\
$\mathrm{~N}$ & \multicolumn{2}{c}{6,515} \\
\hline
\end{tabular}

Note: $H_{0}$ : the Semiparametric (SP) fit can be approximated by a quadratic fit; $H_{1}$ : a quadratic fit cannot approximate the SP fit; reported p-values are bootstrapped with 100 replications. 
TABLE A.2: OLS estimates from quadratic energy share model with household consumption

\begin{tabular}{|c|c|c|}
\hline & Electricity & Other energy \\
\hline $\begin{array}{l}\text { Log of household } \\
\text { consumption }\end{array}$ & $\begin{array}{c}-0.0047^{* * *} \\
(0.0008)\end{array}$ & $\begin{array}{c}-0.0322^{* * *} \\
(0.0020)\end{array}$ \\
\hline Age of household head & $\begin{array}{c}0.0001^{* * *} \\
(0.0000)\end{array}$ & $\begin{array}{c}0.0001^{* * *} \\
(0.0000)\end{array}$ \\
\hline Family size & $\begin{array}{c}-0.0010^{* * *} \\
(0.0002)\end{array}$ & $\begin{array}{c}0.0013^{* * *} \\
(0.0004)\end{array}$ \\
\hline Number of adults & $\begin{array}{c}0.0003 \\
(0.0002)\end{array}$ & $\begin{array}{l}-0.0001 \\
(0.0004)\end{array}$ \\
\hline $\begin{array}{l}\text { Household head has } \\
\text { primary education }\end{array}$ & $\begin{array}{c}0.0001 \\
(0.0006)\end{array}$ & $\begin{array}{l}-0.0001 \\
(0.0010)\end{array}$ \\
\hline Household head has & 0.0007 & -0.0009 \\
\hline $\begin{array}{l}\text { secondary education } \\
\text { Household head has }\end{array}$ & $(0.0006)$ & $(0.0007)$ \\
\hline $\begin{array}{l}\text { Household head has } \\
\text { higher secondary education }\end{array}$ & $\begin{array}{c}0.0023^{\text {PNat }} \\
(0.0009)\end{array}$ & $\begin{array}{l}-0.0002 \\
(0.0011)\end{array}$ \\
\hline $\begin{array}{l}\text { Household head has } \\
\text { graduate degree }\end{array}$ & $\begin{array}{c}0.0013 \\
(0.0013)\end{array}$ & $\begin{array}{c}0.0009 \\
(0.0018)\end{array}$ \\
\hline $\begin{array}{l}\text { Household head has } \\
\text { other education }\end{array}$ & $\begin{array}{c}0.0028 \\
(0.0017)\end{array}$ & $\begin{array}{c}0.0037 \\
(0.0045)\end{array}$ \\
\hline $\begin{array}{l}\text { Spouse of head has } \\
\text { primary education }\end{array}$ & $\begin{array}{l}0.0013^{* *} \\
(0.0005)\end{array}$ & $\begin{array}{c}0.0003 \\
(0.0009)\end{array}$ \\
\hline Spouse of head has & $0.0023^{* * *}$ & $0.0021^{* *}$ \\
\hline secondary education & $(0.0005)$ & $(0.0009)$ \\
\hline $\begin{array}{l}\text { Spouse of head has } \\
\text { higher secondary education }\end{array}$ & $\begin{array}{c}0.0037^{* * *} \\
(0.0011)\end{array}$ & $\begin{array}{l}0.0034^{* *} \\
(0.0015)\end{array}$ \\
\hline $\begin{array}{l}\text { Spouse of head has } \\
\text { graduate degree }\end{array}$ & $\begin{array}{l}0.0040^{* *} \\
(0.0018)\end{array}$ & $\begin{array}{c}0.0051 \\
(0.0032)\end{array}$ \\
\hline $\begin{array}{l}\text { Spouse of head has } \\
\text { other education }\end{array}$ & $\begin{array}{c}0.0080 \\
(0.0075)\end{array}$ & $\begin{array}{c}0.0042 \\
(0.0076)\end{array}$ \\
\hline Urban & $\begin{array}{c}0.0049^{* * *} \\
(0.0006)\end{array}$ & $\begin{array}{c}-0.0057^{* * *} \\
(0.0013)\end{array}$ \\
\hline Residual 1 & $\begin{array}{c}-0.0070^{* * *} \\
(0.0011)\end{array}$ & $\begin{array}{c}0.1784^{* * *} \\
(0.0550)\end{array}$ \\
\hline Residual 2 & & $\begin{array}{c}-0.0095^{* * *} \\
(0.0029)\end{array}$ \\
\hline Constant & $\begin{array}{c}0.2735^{* * *} \\
(0.0507)\end{array}$ & $\begin{array}{c}1.4730^{* * *} \\
(0.2404)\end{array}$ \\
\hline Adjusted $\mathrm{R}^{2}$ & 0.220 & 0.364 \\
\hline $\mathrm{N}$ & 6,515 & 6,515 \\
\hline
\end{tabular}

Note: We reported marginal effects from OLS estimates which include (64) district fixed effects; bootstrapped clustered standard errors are reported in parentheses.

${ }^{*} \mathrm{p}<0.10,{ }^{* *} \mathrm{p}<0.05,{ }^{* * *} \mathrm{p}<0.01$. 
TABLE A.3: OLS estimates from quadratic energy share model with consumption per capita

\begin{tabular}{|c|c|c|}
\hline & Electricity & Other energy \\
\hline $\begin{array}{l}\text { Log of consumption per } \\
\text { capita }\end{array}$ & $\begin{array}{c}-0.0030^{* * *} \\
(0.0008)\end{array}$ & $\begin{array}{c}-0.0335^{* * *} \\
(0.0028)\end{array}$ \\
\hline Age of household head & $\begin{array}{c}0.0001^{* * *} \\
(0.0000)\end{array}$ & $\begin{array}{c}0.0002^{* * *} \\
(0.0000)\end{array}$ \\
\hline Family size & $\begin{array}{c}-0.0019^{* * *} \\
(0.0002)\end{array}$ & $\begin{array}{c}-0.0056^{* * *} \\
(0.0003)\end{array}$ \\
\hline Number of adults & $\begin{array}{c}0.0003 \\
(0.0002)\end{array}$ & $\begin{array}{c}0.0013^{* * *} \\
(0.0005)\end{array}$ \\
\hline $\begin{array}{l}\text { Household head has } \\
\text { primary education }\end{array}$ & $\begin{array}{l}-0.0002 \\
(0.0006)\end{array}$ & $\begin{array}{l}-0.0005 \\
(0.0011)\end{array}$ \\
\hline $\begin{array}{l}\text { Household head has } \\
\text { secondary education }\end{array}$ & $\begin{array}{c}0.0003 \\
(0.0006)\end{array}$ & $\begin{array}{l}-0.0013 \\
(0.0008)\end{array}$ \\
\hline Household head has & $0.0018^{* *}$ & -0.0015 \\
\hline higher secondary education & $(0.0009)$ & $(0.0011)$ \\
\hline $\begin{array}{l}\text { Household head has } \\
\text { graduate degree }\end{array}$ & $\begin{array}{c}0.0007 \\
(0.0013)\end{array}$ & $\begin{array}{l}-0.0003 \\
(0.0019)\end{array}$ \\
\hline $\begin{array}{l}\text { Household head has } \\
\text { other education }\end{array}$ & $\begin{array}{c}0.0021 \\
(0.0018)\end{array}$ & $\begin{array}{c}0.0007 \\
(0.0046)\end{array}$ \\
\hline $\begin{array}{l}\text { Spouse of head has } \\
\text { primary education }\end{array}$ & $\begin{array}{l}0.0011^{* *} \\
(0.0006)\end{array}$ & $\begin{array}{c}0.0008 \\
(0.0010)\end{array}$ \\
\hline $\begin{array}{l}\text { Spouse of head has } \\
\text { secondary education }\end{array}$ & $\begin{array}{c}0.0019^{* * *} \\
(0.0005)\end{array}$ & $\begin{array}{l}0.0023^{* *} \\
(0.0010)\end{array}$ \\
\hline Spouse of head has & $0.0033^{* * *}$ & $0.0036^{* *}$ \\
\hline higher secondary education & $(0.0011)$ & $(0.0015)$ \\
\hline $\begin{array}{l}\text { Spouse of head has } \\
\text { graduate degree }\end{array}$ & $\begin{array}{l}0.0039^{* *} \\
(0.0018)\end{array}$ & $\begin{array}{c}0.0030 \\
(0.0031)\end{array}$ \\
\hline $\begin{array}{l}\text { Spouse of head has } \\
\text { other education }\end{array}$ & $\begin{array}{c}0.0081 \\
(0.0071)\end{array}$ & $\begin{array}{c}0.0055 \\
(0.0072)\end{array}$ \\
\hline Urban & $\begin{array}{c}0.0049^{* * *} \\
(0.0007)\end{array}$ & $\begin{array}{c}-0.0055^{* * *} \\
(0.0013)\end{array}$ \\
\hline Residual 1 & $\begin{array}{c}-0.0073^{* * *} \\
(0.0011)\end{array}$ & $\begin{array}{c}0.2385^{* * *} \\
(0.0735)\end{array}$ \\
\hline Residual 2 & & $\begin{array}{c}-0.0150^{* * *} \\
(0.0046)\end{array}$ \\
\hline Constant & $\begin{array}{c}0.0659^{*} \\
(0.0364)\end{array}$ & $\begin{array}{c}1.4081^{* * *} \\
(0.2844)\end{array}$ \\
\hline Adjusted $\mathrm{R}^{2}$ & 0.194 & 0.337 \\
\hline $\mathrm{N}$ & 6,515 & 6,515 \\
\hline
\end{tabular}

Note: We reported marginal effects from OLS estimates which include (64) district fixed effects; bootstrapped clustered standard errors are reported in parentheses.

${ }^{*} \mathrm{p}<0.10,{ }^{* *} \mathrm{p}<0.05,{ }^{* * *} \mathrm{p}<0.01$. 
TABLE A.4: OLS estimates from quadratic energy share model with consumption equivalised by the OECD scale

\begin{tabular}{|c|c|c|}
\hline & Electricity & Other energy \\
\hline $\begin{array}{l}\text { Log of equivalized } \\
\text { consumption }\end{array}$ & $\begin{array}{l}-0.0040^{* * *} \\
(0.0009)\end{array}$ & $\begin{array}{c}-0.0510^{* * *} \\
(0.0051)\end{array}$ \\
\hline Age of household head & $\begin{array}{c}0.0001^{* * *} \\
(0.0000)\end{array}$ & $\begin{array}{c}0.0003^{* * *} \\
(0.0001)\end{array}$ \\
\hline Family size & $\begin{array}{c}-0.0185^{* * *} \\
(0.0022)\end{array}$ & $\begin{array}{c}-0.0024^{* * *} \\
(0.0002)\end{array}$ \\
\hline Number of adults & $\begin{array}{c}-0.0174^{* * *} \\
(0.0024)\end{array}$ & $\begin{array}{c}-0.0006^{* *} \\
(0.0003)\end{array}$ \\
\hline $\begin{array}{l}\text { Household head has } \\
\text { primary education }\end{array}$ & $\begin{array}{c}0.0062^{* * *} \\
(0.0017)\end{array}$ & $\begin{array}{l}-0.0000 \\
(0.0006)\end{array}$ \\
\hline $\begin{array}{l}\text { Household head has } \\
\text { secondary education }\end{array}$ & $\begin{array}{c}0.0071^{* * *} \\
(0.0018)\end{array}$ & $\begin{array}{c}0.0006 \\
(0.0006)\end{array}$ \\
\hline Household head has & $0.0099^{* * *}$ & $0.0022^{* *}$ \\
\hline higher secondary education & $(0.0024)$ & $(0.0009)$ \\
\hline $\begin{array}{l}\text { Household head has } \\
\text { graduate degree }\end{array}$ & $\begin{array}{c}0.0124^{* * *} \\
(0.0033)\end{array}$ & $\begin{array}{c}0.0012 \\
(0.0013)\end{array}$ \\
\hline $\begin{array}{l}\text { Household head has } \\
\text { other education }\end{array}$ & $\begin{array}{c}0.0032 \\
(0.0046)\end{array}$ & $\begin{array}{l}0.0025 \\
(0.0017)\end{array}$ \\
\hline Spouse of head has & $0.0043^{* * *}$ & $0.0013^{* *}$ \\
\hline primary education & $(0.0013)$ & $(0.0005)$ \\
\hline $\begin{array}{l}\text { Spouse of head has } \\
\text { secondary education }\end{array}$ & $\begin{array}{c}0.0026^{* * *} \\
(0.0010)\end{array}$ & $\begin{array}{c}0.0021^{* * *} \\
(0.0005)\end{array}$ \\
\hline Spouse of head has & $-0.0077^{* * *}$ & $0.0035^{* * *}$ \\
\hline higher secondary education & $(0.0027)$ & $(0.0011)$ \\
\hline $\begin{array}{l}\text { Spouse of head has } \\
\text { graduate degree }\end{array}$ & $\begin{array}{c}-0.0195^{* * *} \\
(0.0060)\end{array}$ & $\begin{array}{l}0.0041^{* *} \\
(0.0018)\end{array}$ \\
\hline $\begin{array}{l}\text { Spouse of head has } \\
\text { other education }\end{array}$ & $\begin{array}{c}0.0196^{* * *} \\
(0.0076)\end{array}$ & $\begin{array}{c}0.0090 \\
(0.0070)\end{array}$ \\
\hline Urban & $\begin{array}{c}-0.0066^{* * *} \\
(0.0013)\end{array}$ & $\begin{array}{c}0.0049^{* * *} \\
(0.0007)\end{array}$ \\
\hline Residual 1 & $\begin{array}{c}0.6667^{* * *} \\
(0.1347)\end{array}$ & $\begin{array}{c}-0.0077^{* * *} \\
(0.0012)\end{array}$ \\
\hline Residual 2 & $\begin{array}{c}-0.0476^{* * *} \\
(0.0096)\end{array}$ & \\
\hline Constant & $\begin{array}{c}2.6997^{* * *} \\
(0.4753)\end{array}$ & $\begin{array}{c}0.0766^{* * *} \\
(0.0164)\end{array}$ \\
\hline Adjusted $\mathrm{R}^{2}$ & 0.361 & 0.213 \\
\hline $\mathrm{N}$ & 6,515 & 6,515 \\
\hline
\end{tabular}

Note: We reported marginal effects from OLS estimates which include (64) district fixed effects; bootstrapped clustered standard errors are reported in parentheses.

${ }^{*} \mathrm{p}<0.10,{ }^{* *} \mathrm{p}<0.05,{ }^{* * *} \mathrm{p}<0.01$. 
TABLE A.5: OLS estimates from quadratic energy share model with consumption equivalised by the square root of family size (SRFS) scale

\begin{tabular}{|c|c|c|}
\hline & Electricity & Other energy \\
\hline $\begin{array}{l}\text { Log of equivalized } \\
\text { consumption }\end{array}$ & $\begin{array}{c}-0.0045^{* * *} \\
(0.0008)\end{array}$ & $\begin{array}{c}-0.0378^{* * *} \\
(0.0026)\end{array}$ \\
\hline Age of household head & $\begin{array}{c}0.0001^{* * *} \\
(0.0000)\end{array}$ & $\begin{array}{c}0.0002^{* * *} \\
(0.0000)\end{array}$ \\
\hline Family size & $\begin{array}{c}-0.0015^{* * *} \\
(0.0002)\end{array}$ & $\begin{array}{c}-0.0019^{* * *} \\
(0.0003)\end{array}$ \\
\hline Number of adults & $\begin{array}{c}0.0004 \\
(0.0002)\end{array}$ & $\begin{array}{l}0.0008^{* *} \\
(0.0004)\end{array}$ \\
\hline $\begin{array}{l}\text { Household head has } \\
\text { primary education }\end{array}$ & $\begin{array}{l}-0.0000 \\
(0.0006)\end{array}$ & $\begin{array}{c}0.0003 \\
(0.0011)\end{array}$ \\
\hline Household head has & 0.0006 & -0.0004 \\
\hline secondary education & $(0.0006)$ & $(0.0008)$ \\
\hline Household head has & $0.0022^{* *}$ & -0.0004 \\
\hline higher secondary education & $(0.0009)$ & $(0.0011)$ \\
\hline $\begin{array}{l}\text { Household head has } \\
\text { graduate degree }\end{array}$ & $\begin{array}{c}0.0011 \\
(0.0013)\end{array}$ & $\begin{array}{c}0.0007 \\
(0.0018)\end{array}$ \\
\hline $\begin{array}{l}\text { Household head has } \\
\text { other education }\end{array}$ & $\begin{array}{l}0.0025 \\
(0.0017)\end{array}$ & $\begin{array}{c}0.0027 \\
(0.0045)\end{array}$ \\
\hline $\begin{array}{l}\text { Spouse of head has } \\
\text { primary education }\end{array}$ & $\begin{array}{l}0.0013^{* *} \\
(0.0005)\end{array}$ & $\begin{array}{c}0.0010 \\
(0.0009)\end{array}$ \\
\hline $\begin{array}{l}\text { Spouse of head has } \\
\text { secondary education }\end{array}$ & $\begin{array}{c}0.0023^{* * *} \\
(0.0005)\end{array}$ & $\begin{array}{c}0.0031^{* * *} \\
(0.0010)\end{array}$ \\
\hline Spouse of head has & $0.0037^{* * *}$ & $0.0044^{* * *}$ \\
\hline higher secondary education & $(0.0011)$ & $(0.0015)$ \\
\hline $\begin{array}{l}\text { Spouse of head has } \\
\text { graduate degree }\end{array}$ & $\begin{array}{l}0.0040^{* *} \\
(0.0017)\end{array}$ & $\begin{array}{c}0.0029 \\
(0.0032)\end{array}$ \\
\hline $\begin{array}{l}\text { Spouse of head has } \\
\text { other education }\end{array}$ & $\begin{array}{c}0.0084 \\
(0.0074)\end{array}$ & $\begin{array}{c}0.0026 \\
(0.0077)\end{array}$ \\
\hline Urban & $\begin{array}{c}0.0050^{* * *} \\
(0.0007)\end{array}$ & $\begin{array}{c}-0.0054^{* * *} \\
(0.0013)\end{array}$ \\
\hline Residual 1 & $\begin{array}{c}-0.0070^{* * *} \\
(0.0012)\end{array}$ & $\begin{array}{c}0.3640^{* * *} \\
(0.0838)\end{array}$ \\
\hline Residual 2 & & $\begin{array}{c}-0.0210^{* * *} \\
(0.0048)\end{array}$ \\
\hline Constant & $\begin{array}{c}0.2025^{* * *} \\
(0.0569)\end{array}$ & $\begin{array}{c}2.2326^{* * *} \\
(0.3491)\end{array}$ \\
\hline Adjusted $\mathrm{R}^{2}$ & 0.206 & 0.356 \\
\hline $\mathrm{N}$ & 6,515 & 6,515 \\
\hline
\end{tabular}

Note: We reported marginal effects from OLS estimates which include (64) district fixed effects; bootstrapped clustered standard errors are reported in parentheses.

${ }^{*} \mathrm{p}<0.10,{ }^{* *} \mathrm{p}<0.05,{ }^{* * *} \mathrm{p}<0.01$. 
TABLE A.6: OLS estimates from cubic energy share model

\begin{tabular}{|c|c|c|}
\hline & Electricity & Other energy \\
\hline $\begin{array}{l}\text { Log of equivalized } \\
\text { consumption }\end{array}$ & $\begin{array}{c}-0.0066^{* * *} \\
(0.0013)\end{array}$ & $\begin{array}{c}-0.0505^{* * *} \\
(0.0050)\end{array}$ \\
\hline Age of household head & $\begin{array}{c}0.0001^{* * *} \\
(0.0000)\end{array}$ & $\begin{array}{l}0.0001^{*} \\
(0.0000)\end{array}$ \\
\hline Family size & $\begin{array}{c}-0.0010^{* * *} \\
(0.0002)\end{array}$ & $\begin{array}{c}0.0016^{* * *} \\
(0.0005)\end{array}$ \\
\hline Number of adults & $\begin{array}{c}-0.0006^{* *} \\
(0.0003)\end{array}$ & $\begin{array}{c}-0.0047^{* * *} \\
(0.0005)\end{array}$ \\
\hline Household head has & 0.0002 & $0.0022^{*}$ \\
\hline primary education & $(0.0006)$ & $(0.0013)$ \\
\hline Household head has & 0.0009 & $0.0021^{*}$ \\
\hline secondary education & $(0.0006)$ & $(0.0012)$ \\
\hline Household head has & $0.0025^{* * *}$ & 0.0006 \\
\hline higher secondary education & $(0.0009)$ & $(0.0012)$ \\
\hline $\begin{array}{l}\text { Household head has } \\
\text { graduate degree }\end{array}$ & $\begin{array}{c}0.0014 \\
(0.0013)\end{array}$ & $\begin{array}{l}-0.0035^{*} \\
(0.0020)\end{array}$ \\
\hline $\begin{array}{l}\text { Household head has } \\
\text { other education }\end{array}$ & $\begin{array}{l}0.0025 \\
(0.0018)\end{array}$ & $\begin{array}{c}-0.0157^{* *} \\
(0.0064)\end{array}$ \\
\hline $\begin{array}{l}\text { Spouse of head has } \\
\text { primary education }\end{array}$ & $\begin{array}{c}0.0016^{* * *} \\
(0.0005)\end{array}$ & $\begin{array}{c}0.0002 \\
(0.0010)\end{array}$ \\
\hline $\begin{array}{l}\text { Spouse of head has } \\
\text { secondary education }\end{array}$ & $\begin{array}{c}0.0026^{* * *} \\
(0.0005)\end{array}$ & $\begin{array}{c}0.0005 \\
(0.0012)\end{array}$ \\
\hline Spouse of head has & $0.0037^{* * *}$ & 0.0008 \\
\hline higher secondary education & $(0.0011)$ & $(0.0017)$ \\
\hline $\begin{array}{l}\text { Spouse of head has } \\
\text { graduate degree }\end{array}$ & $\begin{array}{l}0.0034^{*} \\
(0.0018)\end{array}$ & $\begin{array}{c}0.0167^{* * *} \\
(0.0049)\end{array}$ \\
\hline $\begin{array}{l}\text { Spouse of head has } \\
\text { other education }\end{array}$ & $\begin{array}{c}0.0091 \\
(0.0069)\end{array}$ & $\begin{array}{c}0.0221^{* * *} \\
(0.0078)\end{array}$ \\
\hline Urban & $\begin{array}{c}0.0050^{* * *} \\
(0.0007)\end{array}$ & $\begin{array}{c}-0.0061^{* * *} \\
(0.0013)\end{array}$ \\
\hline Residual 1 & $\begin{array}{l}0.0766^{*} \\
(0.0395)\end{array}$ & $\begin{array}{c}20.3264^{* * *} \\
(5.3729)\end{array}$ \\
\hline Residual 2 & $\begin{array}{c}-0.0048^{* *} \\
(0.0023)\end{array}$ & $\begin{array}{c}-2.3139^{* * *} \\
(0.6154)\end{array}$ \\
\hline Residual 3 & & $\begin{array}{c}0.0875^{* * *} \\
(0.0234)\end{array}$ \\
\hline Constant & $\begin{array}{c}1.4262^{* * *} \\
(0.4053)\end{array}$ & $\begin{array}{c}60.4383^{* * *} \\
(15.4698)\end{array}$ \\
\hline Adjusted $\mathrm{R}^{2}$ & 0.204 & 0.350 \\
\hline $\mathrm{N}$ & 6,515 & 6,515 \\
\hline
\end{tabular}

Note: We reported marginal effects from OLS estimates which include (64) district fixed effects; bootstrapped clustered standard errors are reported in parentheses.

${ }^{*} \mathrm{p}<0.10,{ }^{* *} \mathrm{p}<0.05,{ }^{* * *} \mathrm{p}<0.01$. 